by Shanchi Pengl, 2, Loren E. Babcock ${ }^{3}$, Jingxun Zuo ${ }^{1,4}$, Huanling Lin', Xuejian Zhu ${ }^{1,5}$, Xianfeng Yang ${ }^{1}$, Richard A. Robison ${ }^{6}$, Yuping Qi ${ }^{1}$, Gabriella Bagnoli ${ }^{7}$, and Yong'an Chen ${ }^{8}$

\title{
The Global Boundary Stratotype Section and Point (GSSP) of the Guzhangian Stage (Cambrian) in the Wuling Mountains, Northwestern Hunan, China
}

\author{
1 Nanjing Institute of Geology and Palaeontology, Chinese Academy of Sciences, 39 East Beijing Road, Nanjing 210008, China. \\ Email: scpeng@nigpas.ac.cn \\ 2 State Key Laboratory Paleobiology and Stratigraphy, Chinese Academy of Sciences, 39 East Beijing Road, Nanjing 210008, China \\ 3 School of Earth Sciences, The Ohio State University, 125 South Oval Mall, Columbus, OH 43210, USA. Email: babcock.5@osu.edu \\ 4 Henan Institute of Province Geological Survey, Zhengzhou 450007, China. Email: zuojingxun@yahoo.com.cn \\ 5 Department of Earth Sciences, Nanjing University, Nanjing 210093, China. Email: xuejian_zhu@hotmail.com \\ 6 Department of Geology, University of Kansas, Lawrence, KS 66045, USA. Email: rrobison@ku.edu \\ 7 Department of Earth Sciences of Pisa University, 56126 Pisa, Italy. Email: bagnoli@dst.unipi.it \\ 8 No. 405 Geological Team of Hunan Bureau of Geology and Mineral Resources, Jishou 416007, China.
}

The Global boundary Stratotype Section and Point (GSSP) for the base of the Guzhangian Stage (Cambrian Series 3) is defined at the base of a limestone (calcisiltite) layer $121.3 \mathrm{~m}$ above the base of the Huaqiao Formation in the Louyixi section along the Youshui River (Fengtan Reservoir), about $4 \mathrm{~km}$ northwest of Luoyixi (4 km southeast of Wangcun), in northwestern Hunan, China. The GSSP is exposed in a road cut at a position of $28^{\circ} 43.20^{\prime} N$ and $109^{\circ} 57.88^{\prime}$ E. The GSSP level contains the lowest occurrence of the cosmopolitan agnostoid trilobite Lejopyge laevigata (base of the L. laevigata Zone). Secondary global markers near the base of the stage include the appearance of either L. calva or $\mathrm{L}$. armata just below the base of the stage, the appearance of conodonts associated with the base of the Laiwugnathus laiwuensis Zone, and the transgressive phase of a small eustatic event. Faunal turnovers close to the base of the Guzhangian Stage are recognized as near the base of the Boomerangian Stage in Australia, the base of the Aldanaspis Zone (polymerid trilobites) in Siberia, and the base of the Paradoxides forchhammeri Zone in western Avalonia. The horizon corresponding to the first appearance of $\mathrm{L}$. laevigata is near the peak of a rather long negative $\delta^{13} \mathrm{C}$ excursion of up to $0.58 \%$.

\section{Introduction}

The International Subcommission on Cambrian Stratigraphy (ISCS) has recommended a subdivision of the Cambrian System into four series (Babcock et al., 2005; Peng, 2006; Peng et al., 2006). Within each series it is expected that two to three stages whose boundaries correspond to horizons that can be correlated with a high degree of confidence through all paleocontinents will be recognized. As emphasized by Geyer and Shergold (2000), communication of timestratigraphic information will be maximized if the internal subdivisions of the system correspond to horizons recognizable on all paleocontinents. Traditional, regional stratigraphic schemes, based principally on unit stratotypes, do not meet this goal, and it is for this reason that the ISCS is now engaged in further developing our understanding of key horizons for correlation within the Cambrian, and newly defined series and stages that are readily traceable among Cambrian regions. The newly defined chronostratigraphic units are based on the principle of boundary stratotypes, in which the base of one unit (marked by a Global boundary Stratotype Section and Point, or GSSP) automatically delimits the top of the underlying unit. So defined, these intervals differ in substance from unit stratotypes, which have been variously defined in Cambrian regions (Geyer and Shergold, 2000; Peng et al., 2004a, 2006; Babcock et al., 2005). Apart from the Guzhangian Stage (discussed here), the boundary positions relevant to the Cambrian (Figure 1) that have been ratified are: 1, the conterminant base of the Paleozoic Erathem, Cambrian System, Terreneuvian Series, and Fortunian Stage (Brasier et al., 1994; Landing, 1994; Gehling et al., 2001; Landing et al., 2007); 2, the base of the Drumian Stage (Babcock et al., 2007); 3, the base of the Furongian Series and Paibian Stage (Peng et al., 2004a); and 4, the base of the Ordovician System (Cooper et al., 2001).

At least 11 candidate horizons for global chronostratigraphic correlation have been identified in the upper half of the Cambrian System, based on the first appearance datum (FAD) horizons of intercontinentally distributed agnostoid trilobites (Geyer and Shergold, 2000). To date, three of them have been chosen as the primary stratigraphic tools for correlation of the bases of stages, i.e. the FAD of Ptychagnostus atavus for the Drumian Stage, the FAD of Lejopyge laevigata for the Guzhangian Stage, and the FAD of Glyptagnostus reticulatus for the Paibian Stage. The FAD of the intercontinentally distributed agnostoid trilobite Lejopyge laevigata is one of the most 


\begin{tabular}{|c|c|c|c|}
\hline SYSTEMS & SERIES & STAGES & $\begin{array}{c}\text { BOUNDARY HORIZONS (GSSPS) } \\
\text { OR PROVISIONALSTRATIGRAPHIC TIE POINTS }\end{array}$ \\
\hline Ordovician & Lower & Tremadocian & \multirow{7}{*}{$\begin{array}{l}\text { FAD of lapetognathus fluctivagus (GSSP) } \\
\text { FAD of Lotagnostus americanus } \\
\text { FAD of Agnostotes orientalis } \\
\text { FAD of Glyptagnostus reticulatus (GSSP) } \\
\text { FAD of Lejopyge laevigata: GSSP position }\end{array}$} \\
\hline \multirow{10}{*}{$\frac{z}{\frac{z}{\alpha}}$} & \multirow{3}{*}{$\begin{array}{c}\text { Furongian } \\
\text { Series }\end{array}$} & $\begin{array}{c}\text { Cambrian Stage } 10 \\
\text { (Undefined) }\end{array}$ & \\
\hline & & $\begin{array}{c}\text { Cambrian Stage } 9 \\
\text { (Undefined) }\end{array}$ & \\
\hline & & Paibian Stage & \\
\hline & \multirow{3}{*}{$\begin{array}{l}\text { Cambrian } \\
\text { Series } 3 \\
\text { (Undefined) }\end{array}$} & Guzhangian Stage & \\
\hline & & Drumian Stage & \\
\hline & & $\begin{array}{c}\text { Cambrian Stage } 5 \\
\text { (Undefined) }\end{array}$ & \\
\hline & \multirow{2}{*}{$\begin{array}{l}\text { Cambrian } \\
\text { Series } 2 \\
\text { (Undefined) }\end{array}$} & $\begin{array}{c}\text { Cambrian Stage } 4 \\
\text { (Undefined) }\end{array}$ & \multirow{2}{*}{ ?FAD of Olenellus or Redlichia } \\
\hline & & $\begin{array}{c}\text { Cambrian Stage } 3 \\
\text { (Undefined) }\end{array}$ & \\
\hline & \multirow{2}{*}{$\begin{array}{c}\text { Terreneuvian } \\
\text { Series }\end{array}$} & $\begin{array}{c}\text { Cambrian Stage } 2 \\
\text { (Undefined) }\end{array}$ & \multirow{2}{*}{$\begin{array}{l}\text { FAD of trilobites } \\
\text { ?FAD of SSF species }\end{array}$} \\
\hline & & Fortunian Stage & \\
\hline Ediacaran & & & FAD of Trichophycus pedum (GSSP) \\
\hline
\end{tabular}

Figure 1. Chart showing working model for global chronostratigraphic subdivision of the Cambrian System, indicating lower boundary of the Guzhangian Stage (modified from Babcock et al., 2005).

recognizable levels in the Cambrian (Geyer and Shergold, 2000; Peng and Babcock, 2001; Peng et al., 2001, 2004a; Babcock et al., 2005). A position corresponding closely to the first appearance of $L$. laevigata is recognizable in strata of Gondwana, Baltica, Laurentia, Kazakhstan, and Siberia (e.g., Öpik, 1961, 1979; Ergaliev, 1980; Robison, 1984, 1994; Laurie, 1989; Geyer and Shergold, 2000; Peng and Robison, 2000; Peng and Babcock, 2001; Peng et al., 2001, 2006; Shergold and Geyer, 2003; Babcock et al., 2005, Axheimer et al., 2006), and can be identified with precision using multiple lines of evidence.

The purpose of this paper is to announce ratification of the Guzhangian Stage, the base of which coincides with the FAD of the cosmopolitan trilobite Lejopyge laevigata. The GSSP for the base of the new stage is $121.3 \mathrm{~m}$ above the base of the Huaqiao Formation in the Louyixi section (formerly called the Wangcun South section; Peng et al., 2004c; Peng, 2005; Peng et al., 2005) along the Youshui River (Fengtan Reservoir), about $4 \mathrm{~km}$ northwest of Luoyixi (4 km southeast of Wangcun), in northwestern Hunan, China; Figs. 3, 5, 6, 10). Of the methods that should be given due consideration in the selection of a GSSP (Remane et al., 1996), biostratigraphic, chemostratigraphic, paleogeographic, facies-relationship, and sequence-stratigraphic information is available (e.g., Peng and Robison, 2000; Peng et al., 2001, 2004b), and that information is summarized below. The section is easily accessible, and access for research is unrestricted. It is located on public land under permanent protection by the government of Guzhang County, Hunan. Government protection of this area, a wellknown tourist area with a National Geo-Park, ensures continued free access to the site for research purposes.

For comparative purposes, the FAD of L. laevigata in another excellent section, the Wangcun section, located on the north bank of the Youshui River (opposite the Luoyixi section), Yongshun County, Hunan Province, China (Peng et al., 2001), is also discussed. The
FAD of L. laevigata occurs $121.3 \mathrm{~m}$ above the base of the Huaqiao Formation in the Wangcun section (Peng et al., 2001, 2004b, 2004c). The boundary interval containing the FAD of L. laevigata in the Wangcun section also fulfills all of the geological and biostratigraphic requirements for a GSSP, and is located along a roadcut for which free access for research purposes is granted.

\section{Stratigraphic Rank of the Boundary}

The base of the Guzhangian Stage (Figs. 1,2) will be embraced by a Cambrian series to be named at a future date. Currently the unnamed series is referred to as undefined Cambrian Series 3 (Babcock et al., 2005, 2007; Peng et al., 2006; Figs. 1, 2). The Guzhangian Stage is the third (uppermost) of three stages included in Cambrian Series 3. The base of the stage automatically defines the top of the Drumian Stage, and limits the Drumian to four globally recognized agnostoid trilobite zones, the Ptychagnostus atavus Zone, the Ptychagnostus punctuosus Zone, the Goniagnostus nathorsti Zone, and the Lejopyge armata Zone. The boundary is a standard stage/ age GSSP.

\section{Geography and Physical Geology of the GSSP}

\section{Geographic Location}

The Luoyixi section (Peng et al., 2006) is exposed along a roadcut situated on the south bank of the Youshui River, (Fengtan Reservoir), in the Wuling Mountains (Wulingshan). A number of counties, including Guzhang County, border the river in northwestern Hunan Province, China. The Youshui River forms the boundary between Guzhang County (to the south) and Yongshun County (to the north) in this area (Figs. 3, 4). The roadcut along the opposite bank of the river, which contains the same succession of strata, is referred to as the Wangcun section. Previously, the Luoyixi section was referred to informally as the Wangcun South section (Peng et al., 2004c, 2005). The position of the section is in a roadcut delimited by a cliff represented on topographic map H49 G 0790032, 1:10,000 scale (Surveying and Mapping Bureau of Hunan Province, 1991, 1:10,000 scale; Figure 3D). The Luoyixi section exposes the uppermost part of the Aoxi Formation and more than $200 \mathrm{~m}$ of the overlying Huaqiao Formation. The boundary stratotype for the base of the Guzhangian Stage is in the lower portion of the Luoyixi section. The GSSP is exposed in a roadcut at a position of $28^{\circ} 43.20^{\prime} \mathrm{N}$ latitude and $109^{\circ} 57.88^{\prime}$ E longitude (determined by handheld Garmin GPS), and at an elevation of approximately $216 \mathrm{~m}$.

\section{Geological Location}

The Cambrian geology of northwestern Hunan, the site of the GSSP section, has been summarized in a number of publications, most notably Peng et al. (2001) and papers contained and cited therein. An overview of Cambrian paleogeography, biotic provinces, and 


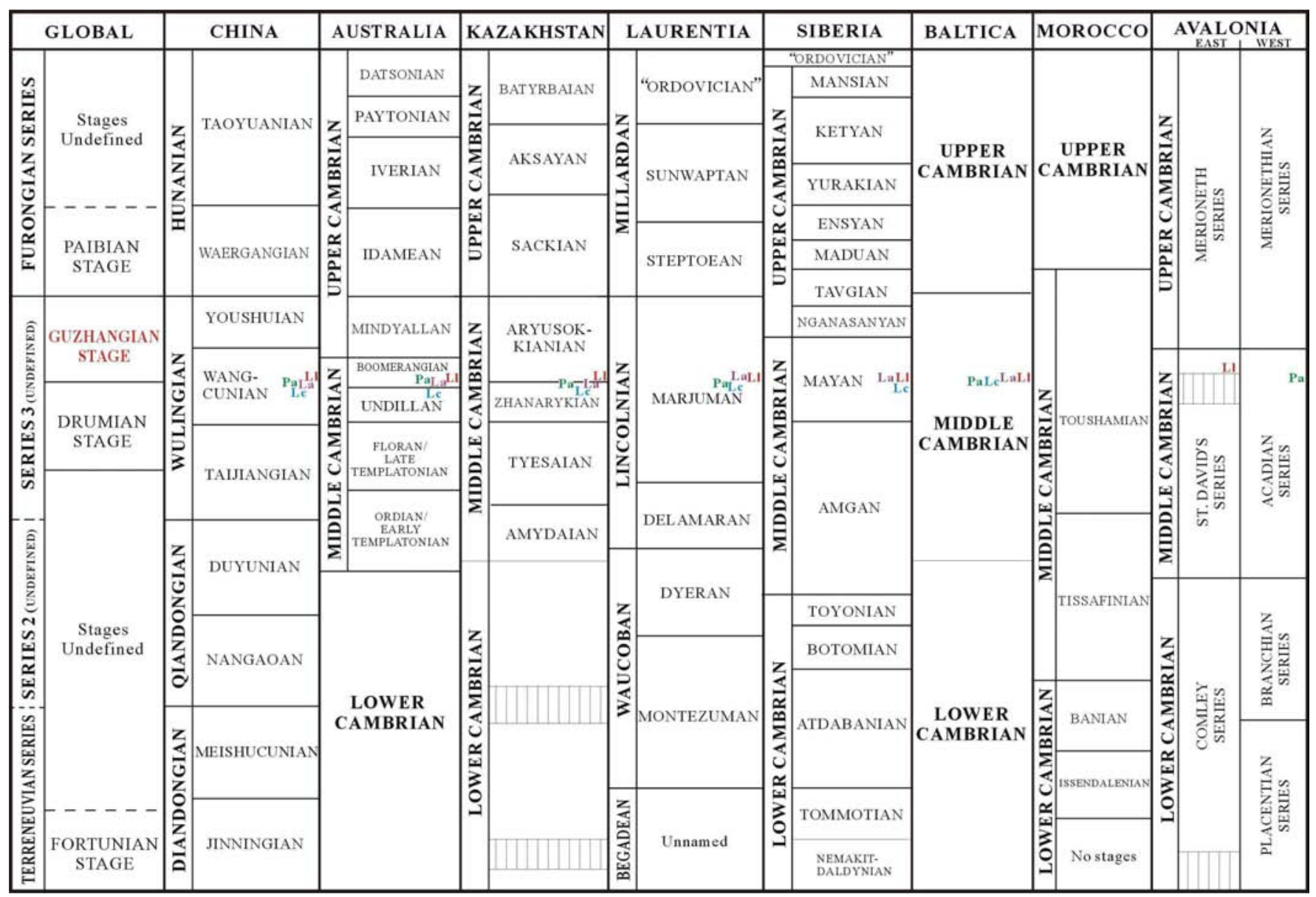

Figure 2. Correlation chart of the Cambrian showing the global chronostratigraphic stages compared to regional usage in major areas of the world (modified from Peng et al., 2004a). Ll indicates the presence and horizon of Lejopyge laevigata in a region; La indicates the presence and horizon of Lejopyge armata in a region; Lc indicates the presence and horizon of Lejopyge calva in a region; Pa indicates the presence and horizon of Ptychagnostus aculeatus in a region. Chart compiled from numerous sources, summarized principally in Geyer and Shergold (2000) and Babcock et al. (2004).

geologic history of the region is contained in Peng and Babcock (2001).

The Wuling Mountains consist of an extensive series of folded and thrusted slices resulting from post-Devonian compressional tectonics that extend through parts of northwestern Hunan, eastern Guizhou, and southeastern Sichuan provinces, China (Guizhou Bureau of Geology and Mineral Resources, 1987; Hunan Bureau of Geology and Mineral Resources, 1988). The Luoyixi section is situated on the southeast limb of an undulating syncline, the Liexi-Zhuitun Syncline. Cambrian strata of South China are assigned to three major depositional environments along a platform-to-basin transition (e.g., Pu and Ye 1991; Peng and Robison 2000; Peng and Babcock 2001). Relatively shallow environments of the Yangtze (South China or Southwest China) Platform were flanked by deeper environments of the Jiangnan Slope Belt, and still deeper environments of the Jiangnan Basin. The GSSP occurs within the Huaqiao Formation, which consists of a thick succession of carbonate beds deposited in the outer part of the Jiangnan Slope Belt (e.g., Pu and Ye, 1991; Rees et al. 1992; Peng and Robison, 2000; Peng and Babcock, 2001).

\section{Location of Level and Specific Point}

The first lenticular calcisiltite limestone layer of the Huaqiao Formation that contains the cosmopolitan agnostoid trilobite Lejopyge laevigata occurs $121.3 \mathrm{~m}$ above the base of the Huaqiao Formation in the Luoyixi section. The species is rare in this bed, but becomes more abundant upsection.

\section{Stratigraphic Completeness}

Detailed correlation of Cambrian Series 3 strata through northwestern Hunan, coupled with detailed biostratigraphy (Peng and Robison, 2000; Peng et al., 2004a, 2004b), sedimentology (Fu et al., 1999; Zuo, 2006; Zuo et al., 2006), and carbon-isotope chemostratigraphy (Zuo, 2006; Zuo et al., 2008; Figures 6, 7), demonstrates the stratigraphic continuity of the basal interval of the Guzhangian Stage in the Luoyixi section. Biostratigraphic studies within Hunan Province and globally demonstrate that the succession of trilobite species (e.g., Westergård, 1946; Daily and Jago, 1975; Öpik, 1961, 1967, 1979; Robison et al., 1977; Ergaliev, 1980; Egorova et al., 1982; Rowell et al., 1982; Robison, 1964a, 1964b, 1984, 1994; Laurie, 1988, 1989; Geyer and Shergold, 2000; Axheimer et al., 2006; Peng et al., 2006) and conodont species (Peng et al., 2006) in the Luoyixi section is undisturbed. The section lacks synsedimentary and tectonic disturbance in the GSSP boundary interval, although minor bedding-plane slippage, which is expected in an inclined succession of strata, occurs along some beds. Bedding-plane-slip surfaces do not appear to have resulted in any loss or repetition of stratigraphic 


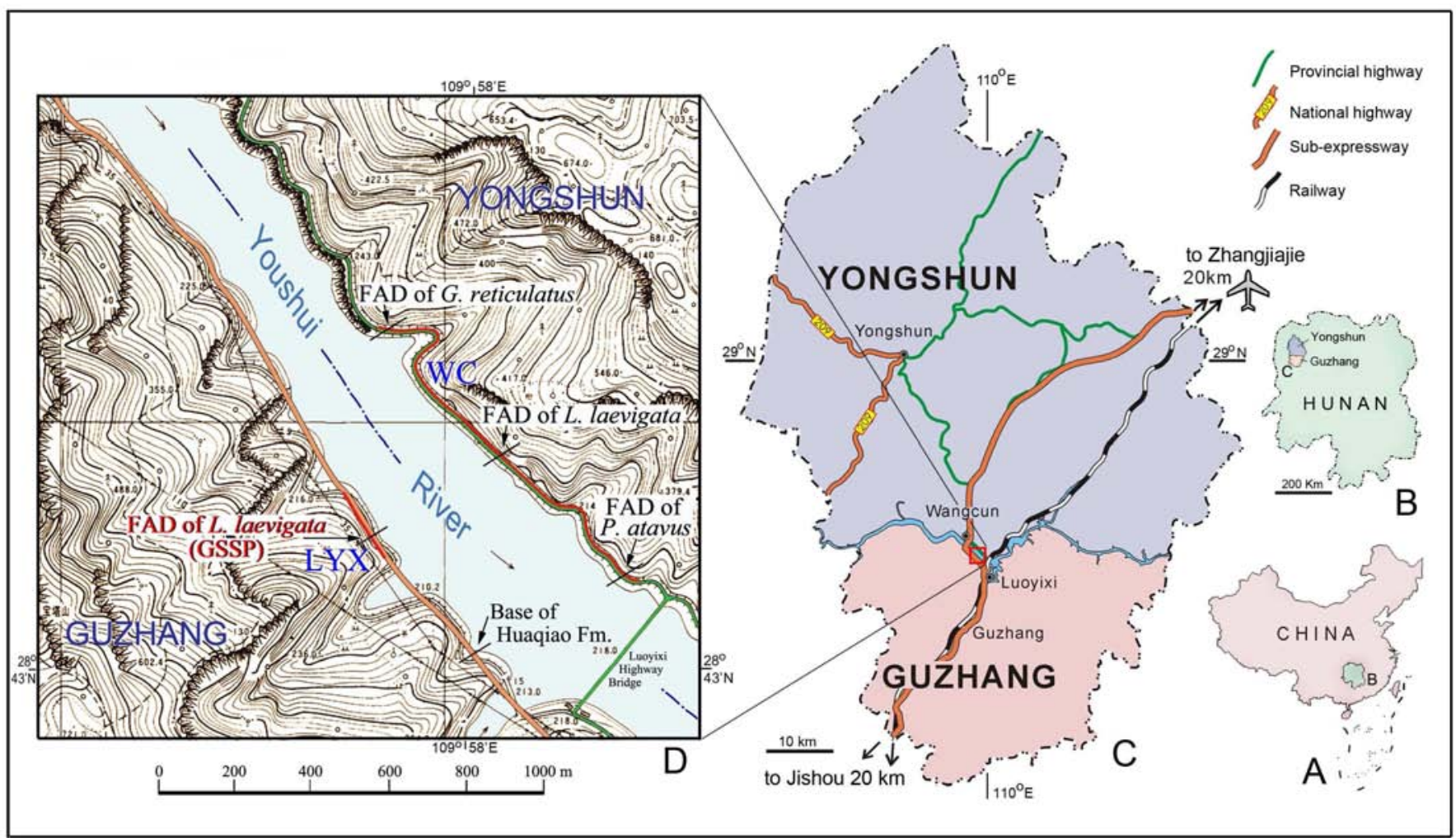

Figure 3. Topographic map of part of northwestern Hunan Province, China, along the Youshui River (Fengtan Reservoir), showing the position of the Luoyixi section (LYX, in northern Guzhang County) and the Wangcun section (WC, in southern Yongshun County). Part D of the figure is from topographic map H49 G 0790032 (Surveying and Mapping Bureau of Hunan Province, 1991, 1:10,000 scale). The position of the GSSP coincides with the FAD of L. laevigata in the Luoyixi section.

thickness, and the biostratigraphic succession in the section is unaffected. There appears to be no evidence of faulting resulting in either loss or repetition of section along the present exposure of the formation. Distal carbonate turbidite beds are present in the section, but weak turbidity currents do not appear to have disrupted the stratigraphic distribution of fossil taxa in the stratotype. Evidence of metamorphism and strong diagenetic alteration is absent.

\section{Thickness and Stratigraphic Extent}

In the Luoyixi section (Figure 5), the Huaqiao Formation consists of a succession of dark, thin-bedded, thinly laminated lime mudstones, argillaceous limestones, and fossiliferous limestone lenses; light-colored ribbon limestones are present in places. In the WangcunLuoyixi area, the Huaqiao Formation includes fine-grained carbonate turbidites and autochthonous carbonate sediments, mostly finegrained, leading to the interpretation that it was deposited in the lower part of an outer slope-apron environment (Fu et al., 1999).

The basal contact of the Guzhangian Stage, marked by the FAD of Lejopyge laevigata, occurs in a mostly monofacial succession of dark gray to black limestones (lime mudstones, or calcimicrites and calcisiltites), and fine-grained argillaceous limestones interbedded with lenses of fossil-rich limestone (calcisiltite). The point where L. laevigata first appears occurs is the lower part of a $0.82 \mathrm{~m}$-thick layer of dark gray, thinly laminated calcisiltite, overlying another layer of thinly laminated, dark-gray calcisiltite (Figure 5C, D). The basal contact of this bed in the Luoyixi section is observable up to the height of the roadcut. The total bedding plane length of the bed is approximately $28 \mathrm{~m}$.

\section{Provisions for Conservation, Protection, and Accessibility}

The exposure containing the GSSP is not subject to building, landscaping, or other destruction. It is located on public land along a road leading to some popular tourist destinations, such as the Fengtan Reservoir, the Hongshiling (Forest of Red Rocks) National Geo-Park, and the historic town of Wangcun. The roadcut is to be permanently managed by the government of Guzhang County.

Access to the outcrop is essentially unrestricted in all seasons. Travel to Hunan is open to persons of all nationalities, and travel for scientific purposes is welcomed. Ordinary vehicles can be driven along the length of the section, and can be parked adjacent to the GSSP point.

\section{Motivation for Selection of the Boundary Level and of the Stratotype Section}

\section{Principal Correlation Event (marker) at GSSP Level}

The agnostoid trilobite Lejopyge laevigata (Figure 9H-J) has one of the broadest distributions of any Cambrian trilobite (e.g., Westergård, 1946; Pokrovskaya, 1958; Öpik, 1961, 1979; Palmer, 1968; Khairullina, 1970, 1973; Robison et al., 1977; Yang, 1978, Ergaliev, 1980; Egorova et al., 1982; Robison, 1984, 1988, 1994; Laurie, 1989; Lu and Lin, 1989; Yang et al., 1991; Dong , 1991; Tortello and Bordonaro, 1997; Geyer and Shergold, 2000; Peng and Robison, 2000; Jago and Brown, 2001; Babcock et al., 2004, 2005; Axheimer et al., 2006; Peng et al., 2006), and its first appearance has 


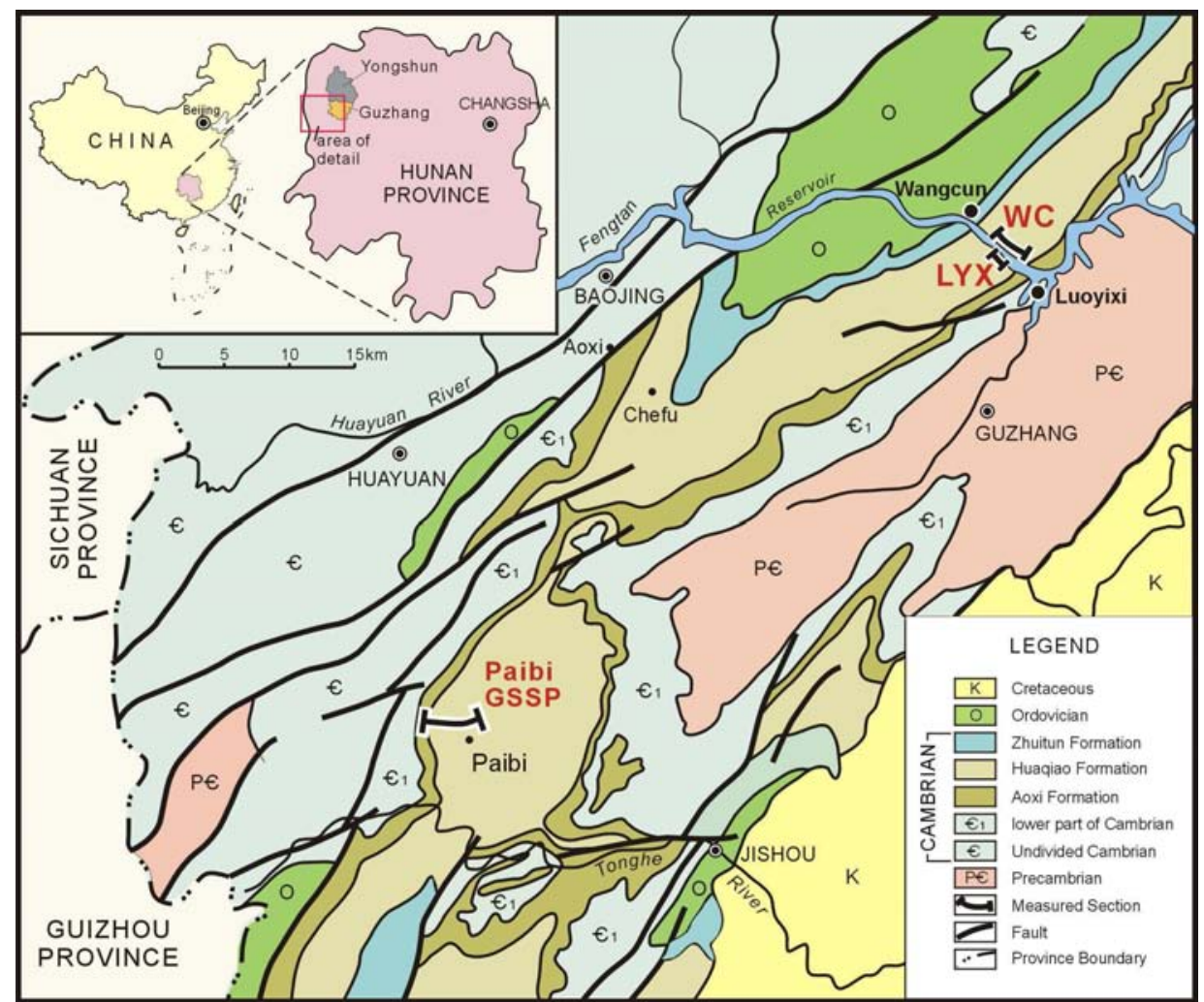

Figure 4. Map of part of northwestern Hunan Province (location of Hunan inset), China, showing location of the stratotype section for the Guzhangian Stage (Luoyixi section, south side of the Fengtan Reservoir, Youshui River; indicated as LYX). Location of the Wangcun section (north side of the Fengtan Reservoir, Youshui River) is indicated as WC. For reference, location of the Paibi section, stratotype of the Furongian Series and Paibian Stage (indicated as Paibi GSSP), is also indicated. Map modified from Peng et al. (2004b).

been acknowledged as one of the most favorable levels for a GSSP defining the base of a global Cambrian stage (e.g., Robison et al., 1977; Rowell et al., 1982; Robison, 1999, 2001; Geyer and Shergold, 2000; Shergold and Geyer, 2001; Babcock et al., 2004; Peng et al., 2006). Agnostoid trilobites provide the best and most precise tools for intercontinental correlation in the upper half of the Cambrian System (e.g., Robison, 1984; Peng and Robison, 2000). Recent recalibration of radiometric ages for the Cambrian (Grotzinger et al., 1995; Davidek et al., 1998; Landing et al., 1998, 2000), scaled against the number of agnostoid zones recognized in the upper half of the Cambrian, indicates that the average duration of an agnostoid-defined biochron is about one million years (Peng and Robison, 2000). Lejopyge laevigata has been identified from Argentina, Australia, China, Denmark, England, Germany (in glacial erratics), Greenland, India, Kazakhstan, Norway, Poland, Turkestan, Uzbekistan, Russia, Sweden, and the United States, and has been used as a zonal guide fossil in deposits of Baltica, Gondwana, Kazakhstania, Siberia, Laurentia, and eastern Avalonia (e.g., Westergård, 1946; Cowie et al., 1972; Robison, 1976, 1984; Öpik, 1979; Shergold et al., 1985; Geyer and Shergold, 2000; Peng and Robison, 2000; Axheimer et al., 2006; Peng et al., 2006). The base of the Boomerangian Stage in Australia corresponds to the base of the L. laevigata Zone (Öpik, 1967; Shergold et al., 1985; Geyer and Shergold, 2000; Axheimer et al., 2006). In western Avalonia, the base of the Paradoxides forchhammeri Zone corresponds approximately to the base of the $L$. laevigata Zone (Geyer and Shergold, 2000). By using the first appearance of L. laevigata, rather than its local abundance, the base of the Scandinavian L. laevigata Zone can be extended downward so that the revised L. laevigata Zone in Scandinavia embraces the traditional Solenopleura? brachymetopa Zone (Axheimer et al., 2006).

Stratigraphically, the first appearance of Lejopyge laevigata (Figures 5B-D, 6, 7) always succeeds the first appearance of at least one other species of Lejopyge. In China, Kazakhstan, and Tasmania, where three Lejopyge species are present, the stratigraphic order of appearance is $L$. calva (at times assigned to Pseudaphalacroma dubium or Pseudophalacroma? sp.), followed by L. armata, and then followed by L. laevigata (Jago, 1975, Ergalieva, 1980, Peng and Robison, 2000). In Antarctica, L. calva is also followed by L. armata (Cooper et al., 1996). In Laurentia, however, the order of succession is L. calva followed by L. laevigata, followed by $L$. armata. The reason for the discrepancy in the first appearance of $L$. armata in Laurentia is unknown, but it may relate to limits on the exposure of favorable biofacies and stratigraphic occurrence. Morphological features of $L$. calva suggest it may be an ancestor of both of L. armata and L. laevigata. Species of Lejopyge always succeed the FAD of the agnostoid Goniagnostus nathorsti, which is the eponymous guide fossil for the G. nathorsti Zone, and they always succeed the FAD of Ptychagnostus punctuosus, which is the eponymous guide fossil for the $P$. punctuosus Zone. It is desirable to select the position of a GSSP in a section showing a complete succession from the P. punctuosus Zone (or the G. nathorsti Zone and the $L$. armata Zone if recognized regionally) through the $L$. laevigata Zone. In a complete succession, the LADs of both $L$. calva and $L$. armata should fall within the L. laevigata Zone, and L. calva should be in the lowermost part of the zone. Selection of the FAD of L. laevigata as the primary correlation tool for the base of a Cambrian stage ensures that the boundary will fall within a stratigraphic interval bearing agnostoid trilobites, many of which are phylogenetically related. Globally, the stratigraphic interval bearing the overlap between L. calva, L. armata, and L. laevigata is relatively narrow but widely recognizable. Together, the narrow stratigraphic overlap of Lejopyge species (if more than one species is present), and the stratigraphic disappearance of both P. punctuosus and G. nathorsti, allows the boundary to be tightly constrained as long as ptychagnostid-bearing strata are present in a region.

Selection of a GSSP in an open-shelf to basinal deposit, and particularly in one from a low-latitude region such as the South China (Yangtze) Platform, is desirable because it provides faunal ties and correlation with low-latitude open-shelf areas, high-latitude openshelf areas, and low- or high-latitude, slope-to-basinal areas. In the latter half of the Cambrian, stratification of the world ocean according to temperature or other factors that covary with depth (e.g., Cook and 


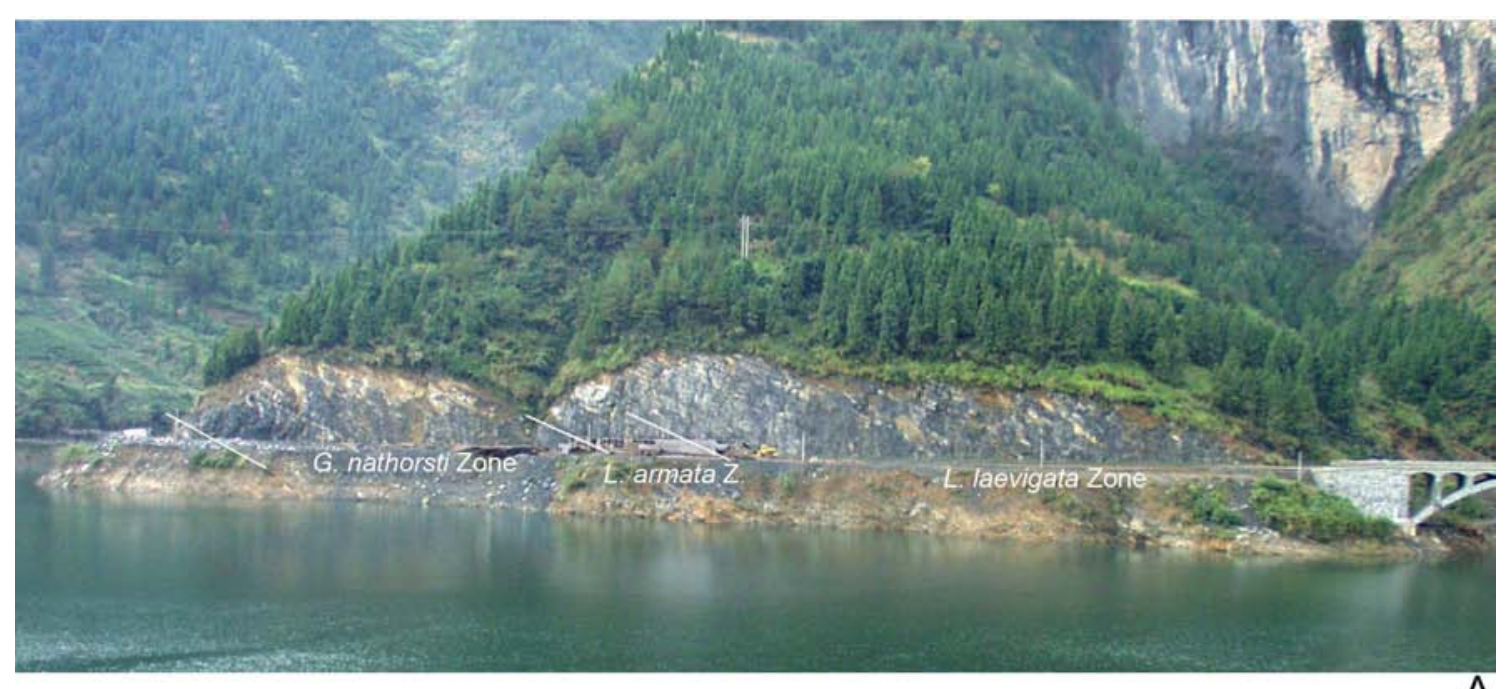

A

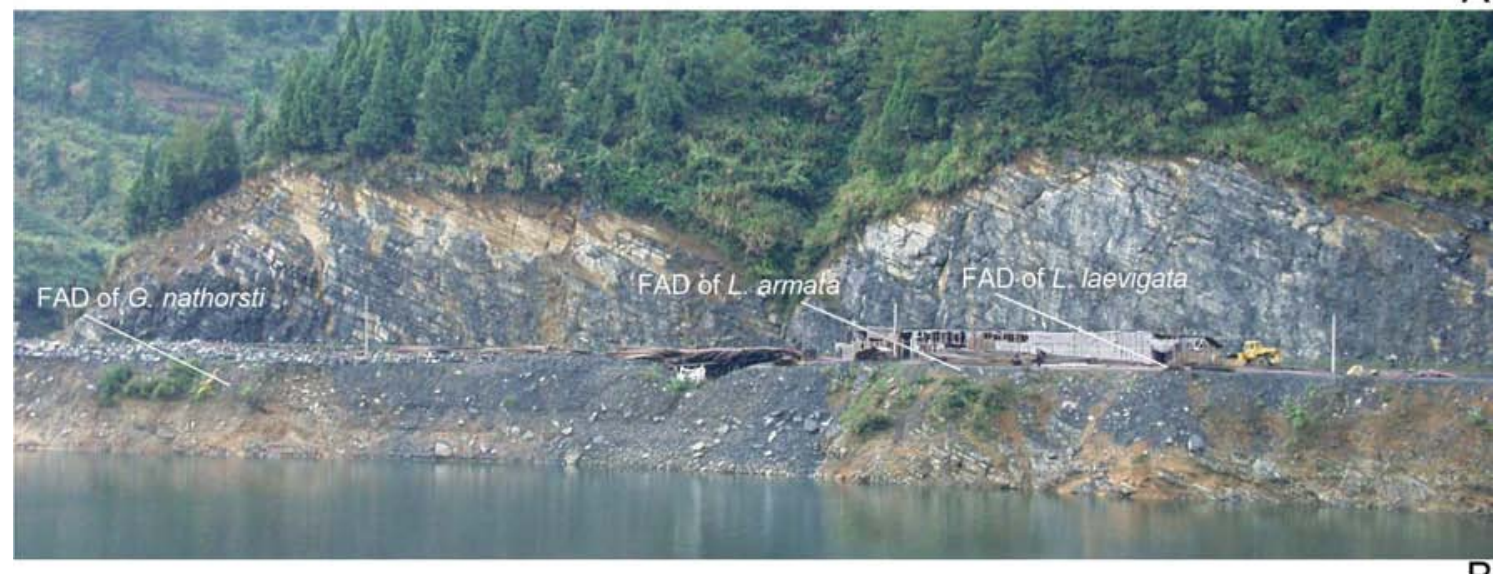

B
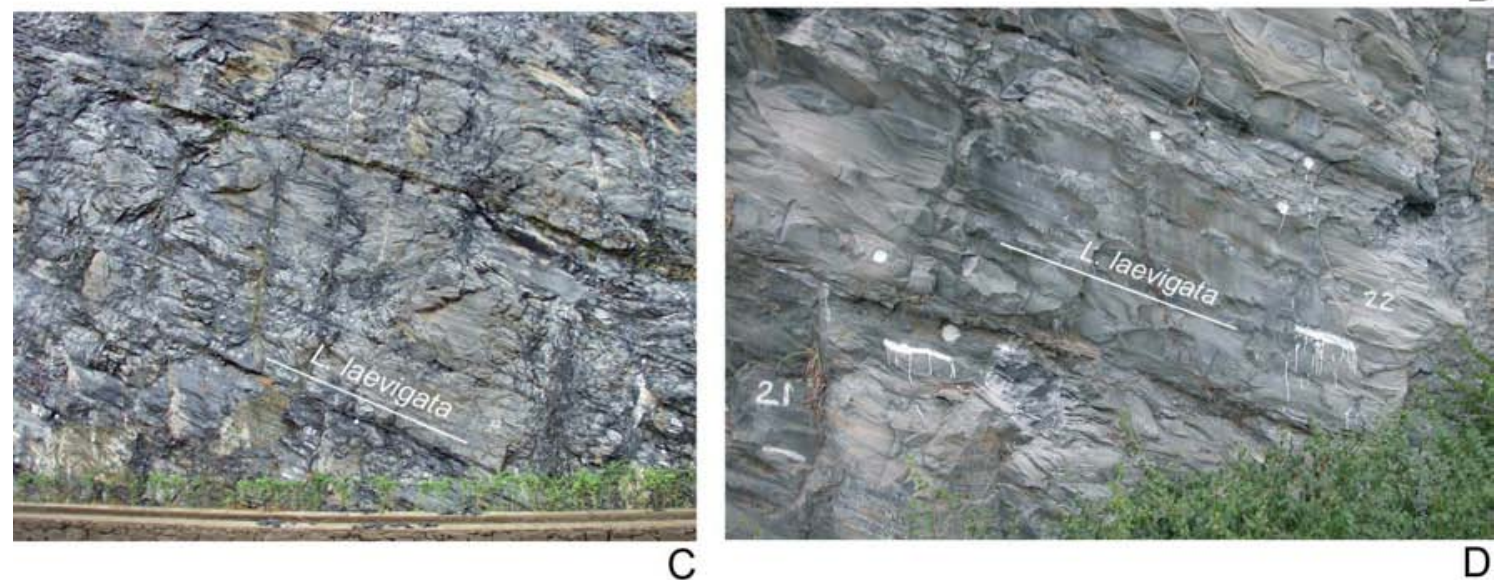

Figure 5. Exposure of the GSSP for the base of the Guzhangian Stage (coinciding with the FAD of Lejopyge laevigata) in the Huaqiao Formation, Luoyixi section, Guzhang County, Hunan Province, China. Strata underlying the Guzhangian GSSP belong to the Drumian Stage. A, Southwestern bank of Youshui River (Fengtan Reservoir) showing the Luoyixi section. B, Lower part of the Luoyixi section. C, D, Progressively closer views of the Luoyixi section showing the FAD of $\mathrm{L}$. laevigata (marked by a white line), $121.3 \mathrm{~m}$ above the base of the Huaqiao Formation.

Taylor, 1975, 1976; Babcock, 1994) led to the development of rather distinct trilobite biofacies in shelf and basinal areas. Low-latitude shelf areas were inhabited mostly by endemic polymerid trilobites and some pan-tropical taxa. High-latitude shelf areas, and basinal areas of low and high latitudes, were inhabited mostly by widespread polymerid trilobites and cosmopolitan agnostoid trilobites. Slope areas are characterized by a combination of some shelf-dwelling taxa and basin-dwelling taxa. A combination of cosmopolitan agnostoids, which have intercontinental correlation utility, shelf-dwelling polymerids, which mostly allow for intracontinental correlation, and pan-tropical polymerids, which allow for limited intercontinental correlation, provides for precise correlation of the base of the L. laevigata Zone through much of Gondwana. Likewise, the combination of these taxa provides for precise correlation of the base of the zone into areas of 
Baltica, Siberia, Laurentia, Kazakhstan, and eastern Avalonia, and reasonably good correlation into western Avalonia (Hutchinson, 1962; Geyer and Shergold, 2000).

\section{Stratotype Section}

The FAD of L. laevigata in the Luoyixi section, Hunan Province, China (Figures 3, 5, 6), occurs in the Huaqiao Formation at a level $121.3 \mathrm{~m}$ above the base of the formation (Figures 5C, 5D, 6). At this section, and in the Wangcun section as well, the Huaqiao Formation rests on the Aoxi Formation. The Aoxi-Huaqiao contact is inferred to be a sequence boundary representing a major eustatic rise (transgressive event). Agnostoid trilobite zonation of the Huaqiao Formation in the measured section reveals a complete, tectonically undisturbed, marine succession through much of the Drumian Stage (lower part of the P. atavus Zone through the P. punctuosus, G. nathorsti and $L$. armata zones), through all of the Guzhangian Stage, and into the overlying Paibian Stage (Furongian Series). The Huaqiao Formation in the Luoyixi section is a mostly monofacial succession of dark, fine-grained limestones (Figure 5). Small truncation surfaces, and slide surfaces reflecting distal turbidite deposition are rare in the section and absent near the GSSP, suggesting deposition in an outer slope to carbonate apron environment (Rees et al., 1992).

The GSSP in the Luoyixi section lies within a long, apparently complete stratigraphic succession beginning in the uppermost part of the Drumian Stage and containing an assemblage of agnostoid trilobites, most of which are phylogenetically related ptychagnostid species. Successive stratigraphic levels show a succession beginning with Goniagnostus nathorsti (79.4 m above the base of the Huaqiao Formation) and continuing through the FADs of L. armata $(111.9 \mathrm{~m}$ above the base of the formation), Lejopyge laevigata $(121.3 \mathrm{~m}$, marking the base of the Guzhangian Stage), and Proagnostus bulbus (215.7 m). The section appears to be continuous through the entire $L$. laevigata Zone, the Proagnostus bulbus Zone, the Linguagnostus reconditus Zone, and the Glyptagnostus stolidotus Zone to the base of the Paibian Stage (marked by the base of the Glyptagnostus reticulatus Zone). In the bed containing the lowest $L$. laevigata in the section $(121.3 \mathrm{~m})$, the species is rather rare. L. laevigata remains uncommon through the first $40 \mathrm{~m}$ of its range in the Luoyixi section.

Observed ranges of trilobites across the stratigraphic interval containing the GSSP are summarized in Figure 6. Besides L. laevigata, a number of other guide fossils, important for intercontinental correlation, help to constrain the boundary position. They include the LADs of L. calva and G. nathorsti, both of which occur below the FAD of L. laevigata. Ptychagnostus atavus ranges from the base of the Drumian Stage through the lowermost part of the L. laevigata Zone (lowermost part of the Guzhangian Stage). The FADs of Clavagnostus trispinus, Linguagnostus kjerulfi, and Ptychagnostus aculeatus occur slightly below the base of the L. laevigata Zone, whereas the FAD of Utagnostus neglectus occurs in the lowermost part of the L. laevigata Zone.

Observed ranges of polymerid trilobites, some of which have utility for correlation on a regional scale, serve as secondary biostratigraphic correlation tools for identifying the base of the Guzhangian Stage (Peng et al., 2004b, 2006). A diverse assemblage

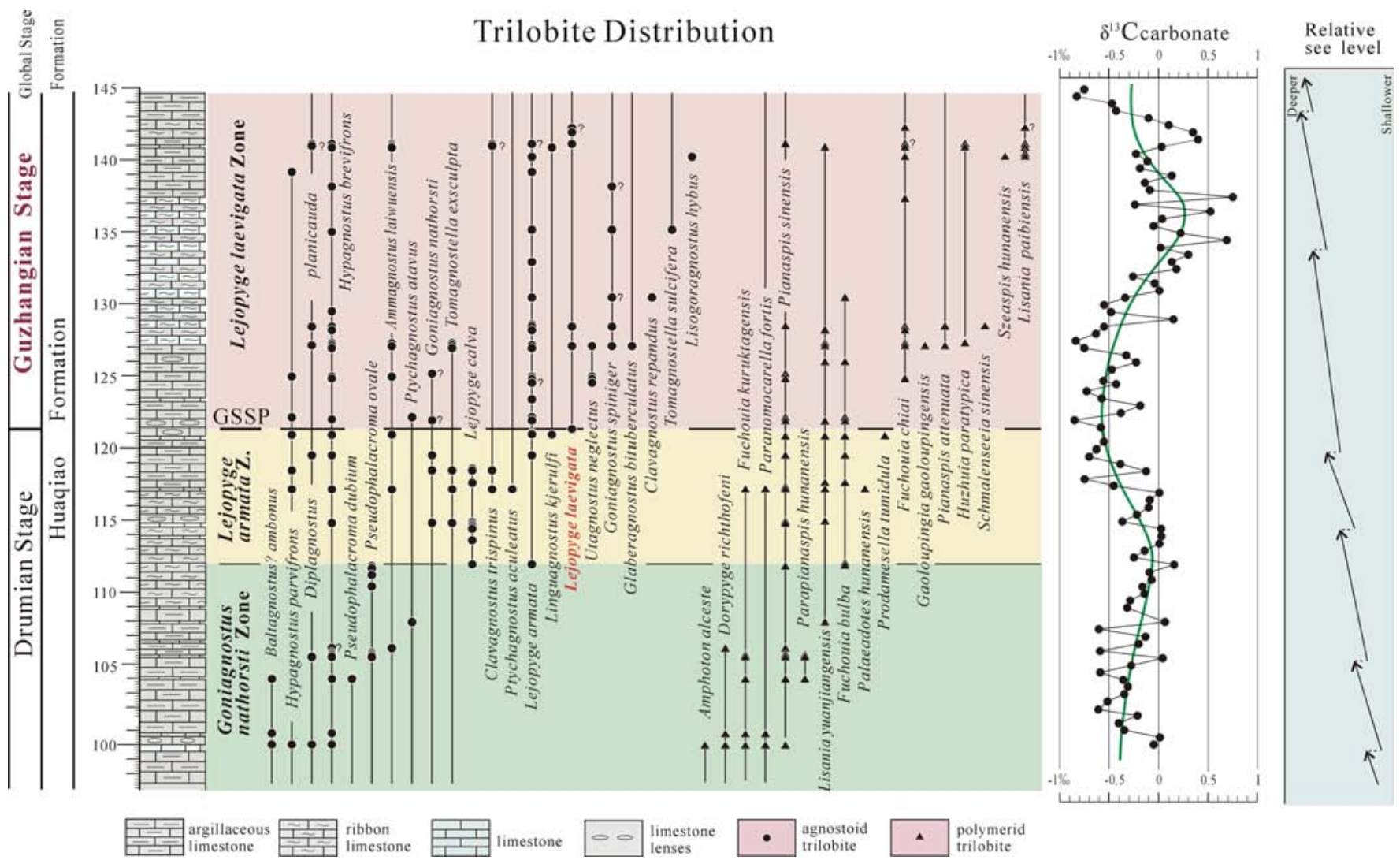

Figure 6. Observed stratigraphic distribution of trilobites in the Huaqiao Formation near the base of the Lejopyge laevigata Zone, Luoyixi section, Guzhang County, Hunan Province, China. The GSSP coincides with the base of the L. laevigata Zone in this section. An interpretive sea level history, reflecting small-scale regional or eustatic changes, is added for comparison. Also added for comparison is a curve of $\delta^{13} \mathrm{C}$ isotopic values, derived from samples collected from the Luoyixi section. 
of polymerid trilobites belonging to the Pianaspis sinensis Zone range through the G. nathorsti Zone and into the L. laevigata Zone. P. sinensis, Fuchouia chiai, Lisania yuanjiangensis, Lisania paratungjenensis, Amphoton alceste and Prodamesella tumidula disappear before the FAD of L. laevigata. The LADs of Fuchouia bulba and Qiandongensis convexa are in the lowermost part of the $L$. laevigata Zone.

Conodonts (Figure 11) help to constrain the base of the Guzhangian Stage in the Luoyixi section, the stratotype (Figures 7, $10)$, although the zonation is not as precise as that afforded by trilobites. The first observed elements of Shandongodus priscus (the eponymous species of the $S$. priscus Zone) in the Luoyixi section occur in the lower part of the L. laevigata Zone.

\section{Regional and Global Correlation}

A position at or closely corresponding to the FAD of L. laevigata in the Luoyixi section is one of the most easily recognizable horizons on a global scale in the Cambrian (e.g., Geyer and Shergold, 2000; Figure 2). Suitability of the FAD of this species for marking a global stage and series boundary has been summarized principally by Geyer

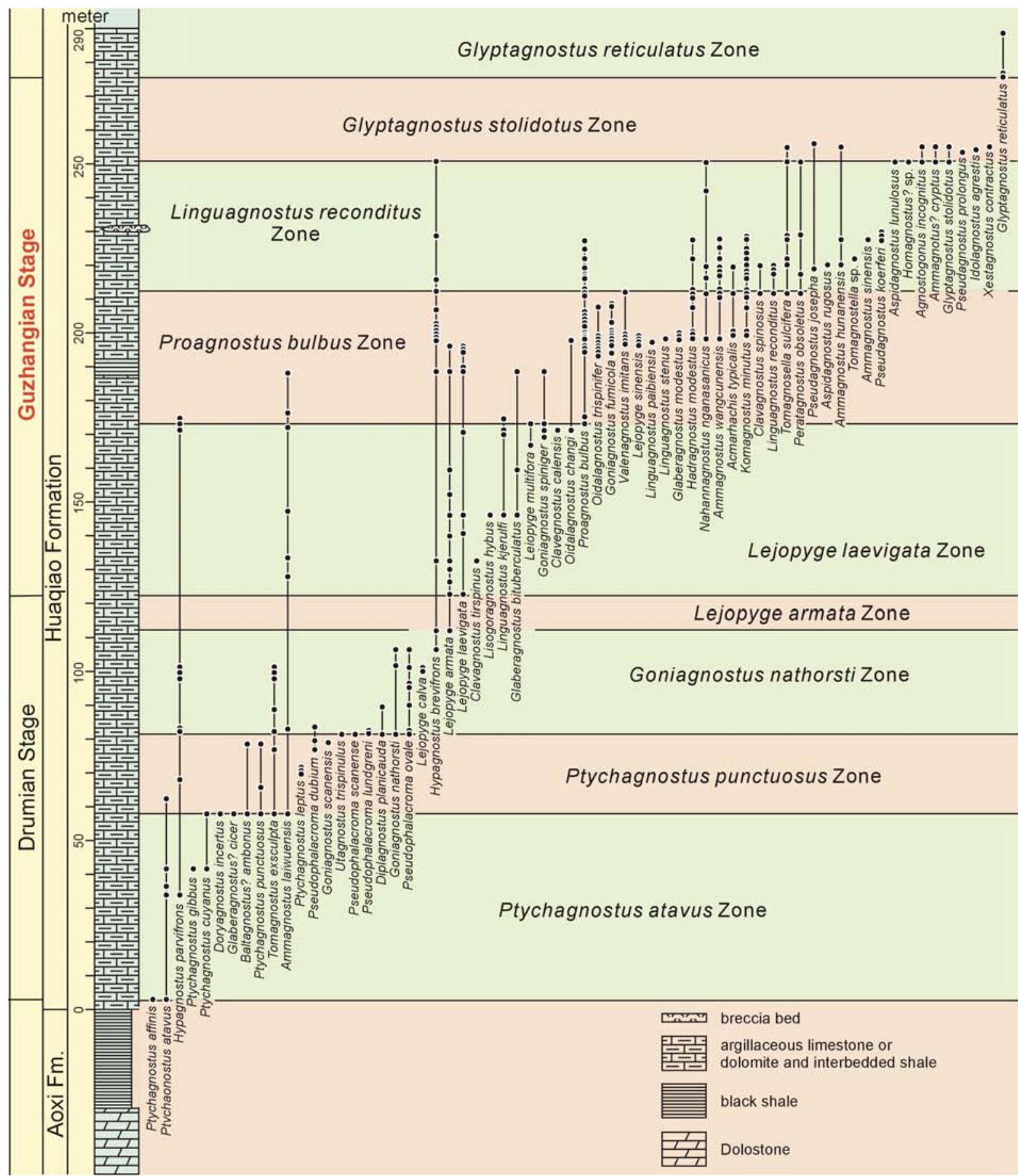

Figure 7. Observed stratigraphic distribution of agnostoid trilobites in the Huaqiao Formation, Wangcun section, on the northeastern bank of the Youshui River, Yongshun County, Hunan Province, China, added for comparison with the Luoyixi section, which is on the southwestern bank of the same river (modified from Peng and Robison, 2000). 


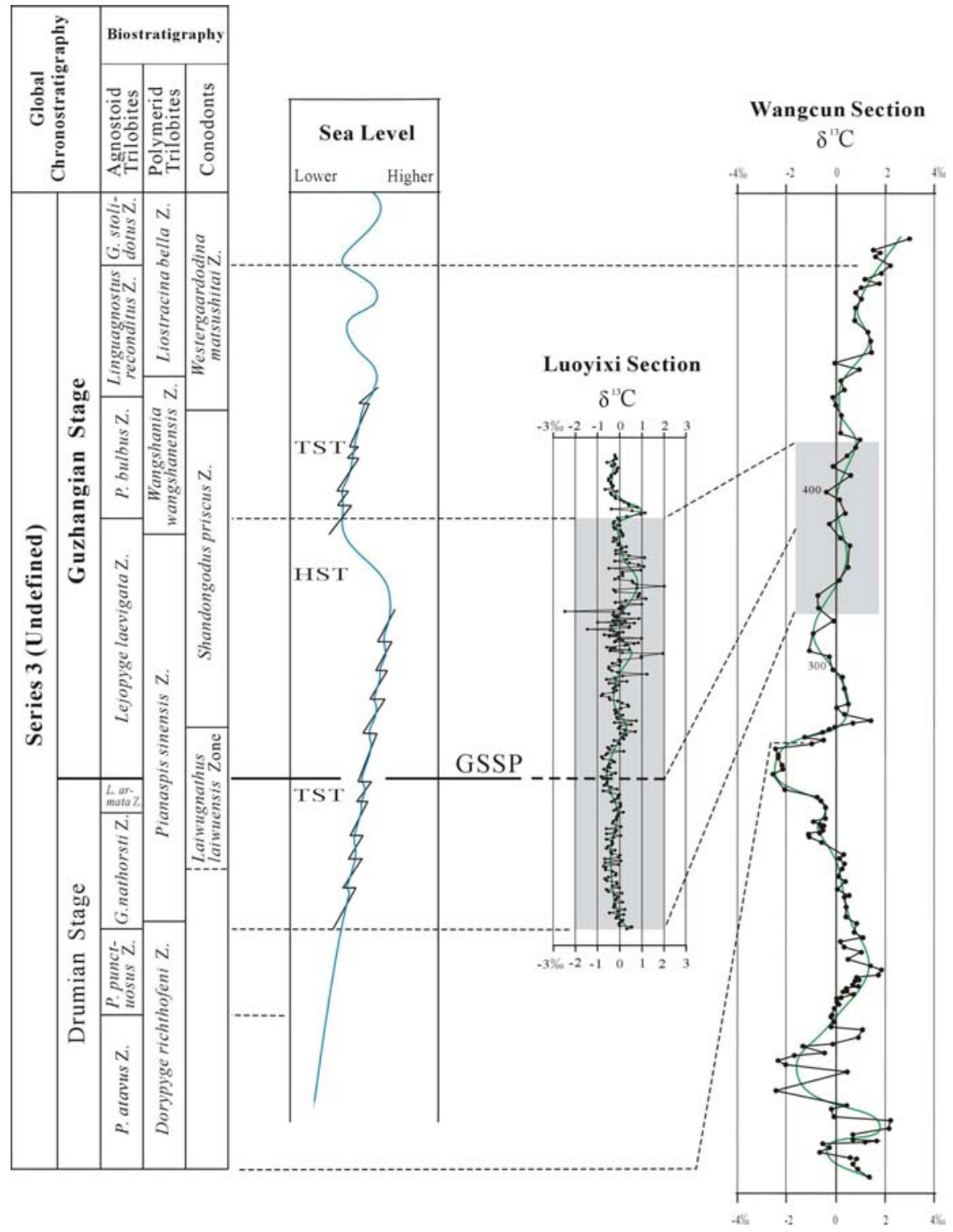

Figure 8. Summary of primary and secondary stratigraphic indicators for the base of the Guzhangian Stage of the Cambrian System. Major stratigraphic tools used to constrain the GSSP of the Guzhangian Stage are the zonation of agnostoid trilobites (Peng and Robison, 2000; Peng et al., 2006), the zonation of polymerid trilobites (Peng et al., 2004b; Peng et al., 2006), the zonation of conodonts (Peng et al., 2006), carbon isotope chemostratigraphy (records from the Luoyixi and Wangcun sections from Zuo, 2006; Zhu et al, 2004), and sequence stratigraphy (Zuo, 2006). All these techniques can be applied in the Luoyixi section, the stratotype. Two orders of inferred sea level history are illustrated: third order (in blue) and fourth order (in black).

and Shergold (2000), and Peng et al. (2004c, 2006). Key correlation tools are described in the following subsections.

\section{Agnostoid Trilobite Biostratigraphy}

Lejopyge laevigata has been recognized worldwide (e.g., Westergård, 1946; Pokrovskaya, 1958; Öpik, 1961, 1979; Demokidov, 1968; Palmer, 1968; Khairullina, 1970, 1973; Robison et al., 1977; Yang, 1978, Ergaliev, 1980; Egorova et al., 1982; Robison, 1984, 1988, 1994; Laurie, 1989; Lu and Lin, 1989; Yang et al., 1991; Dong, 1991; Tortello and Bordonaro, 1997; Geyer and Shergold, 2000; Peng and Robison, 2000; Jago and Brown, 2001; Babcock et al., 2004, 2005; Peng et al., 2004b, 2006; Axheimer et al., 2006; Figure 2), and Bergström, 2001).

\section{Chemostratigraphy}

having been identified from rocks of Argentina, Australia (western Queensland, Tasmania), China (Guizhou, Hunan, Sichuan, Xinjiang, Zhejiang), Denmark (Bornholm), England, Germany (erratics), North Greenland, India (Ladakh), Kazakhstan (Malyi Karatau), Kyrgyzstan, Norway, northern Poland, Russia (southern and northeastern Siberian Platform), Sweden, Turkestan, Uzbekistan, and the United States (Nevada, Alaska). The species has been used as a zonal guide fossil in deposits of Baltica, Gondwana, Kazakhstan, Siberia, Laurentia, and eastern Avalonia (e.g., Westergård, 1946; Cowie et al., 1972; Robison, 1976, 1984; Öpik, 1979; Ergaliev and Ergaliev, 2000; Geyer and Shergold, 2000; Peng and Robison, 2000; Ergaliev and Ergaliev, 2000, 2001; Axheimer et al., 2006). Co-occurrences with other trilobites allow for a close correlation into western Avalonia (near the base of the Paradoxides forchhammeri Zone; Geyer and Shergold, 2000).

\section{Polymerid trilobite Biostratigraphy}

The base of the L. laevigata Zone coincides with a change in polymerid trilobite faunas recognized near the base of the Boomerangian Stage in Australia (Öpik, 1967; Geyer and Shergold, 2000; Figure 2) and the base of the Aldanaspis Zone in Siberia (Egorova et al., 1982). It also approximately coincides with a faunal change associated with the base of the Paradoxides forchhammeri Zone in western Avalonia (Geyer and Shergold, 2000).

\section{Conodont Biostratigraphy}

Two conodont zones are recognized in the Luoyixi section, with terminology adapted from North China usage (An, 1982). A position near the base of the L. laevigata Zone corresponds with a change in conodont faunas (Figure 10). The interval from $117.2 \mathrm{~m}$ to $121.0 \mathrm{~m}$, assigned to the Laiwugnathus laiwuensis Zone, is characterized by the first appearances of paracondonts such as Yongshunella polymorpha, Furnishina bigeminata,

$F$. kleithria, and $F$. cf. alata. The eponymous guide fossil Laiwugnathus laiwuensis occurs immediately below the FAD of $L$. laevigata. The lower boundary of the Shandongodus priscus Zone is in the lower quarter of the L. laevigata Zone in the stratotype section. In the Wangcun section, conodont faunas show an increase in diversity above the lower boundary of the S. priscus Zone (Dong

The base of the L. laevigata Zone is not marked by a distinctive shift in carbon isotopic values (Figure 6), although its position can be recognized from a longer sequence of $\delta^{13} \mathrm{C}$ values. The horizon 


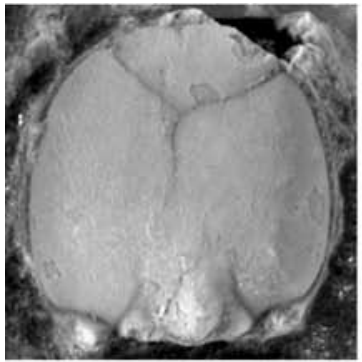

A

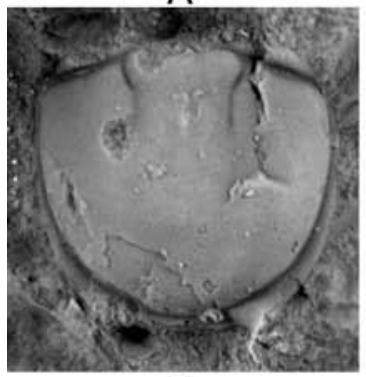

B

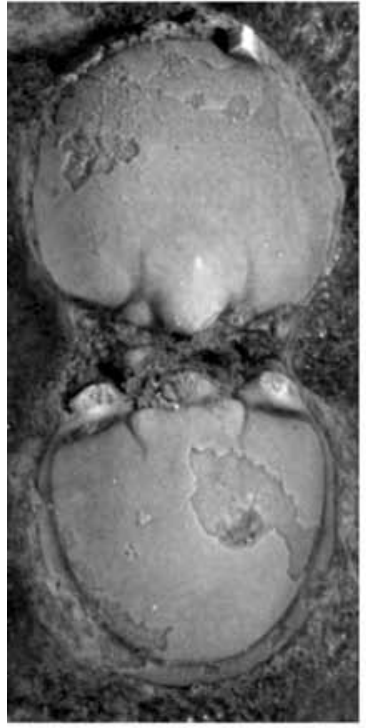

$\mathrm{H}$

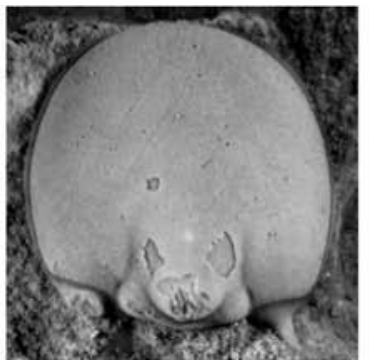

C

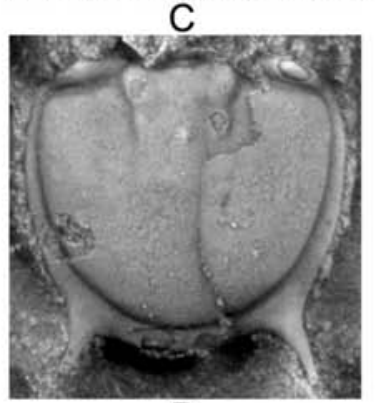

D

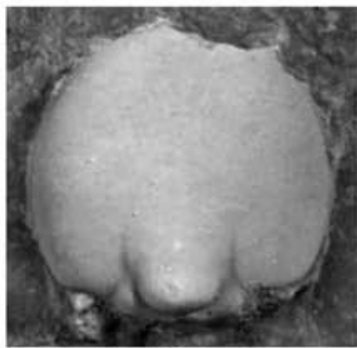

I

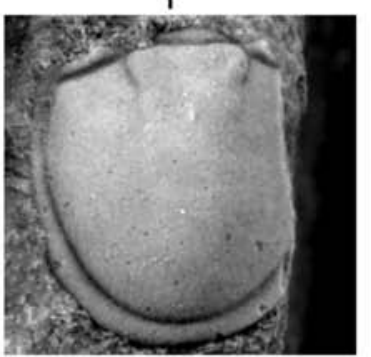

$\mathrm{J}$

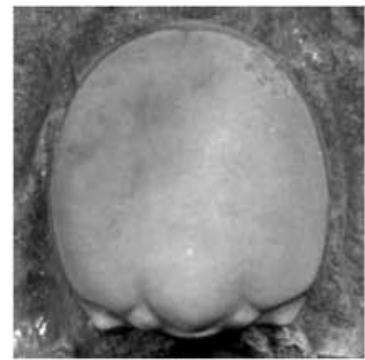

E

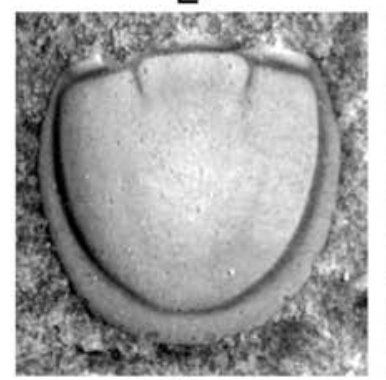

$\mathrm{F}$

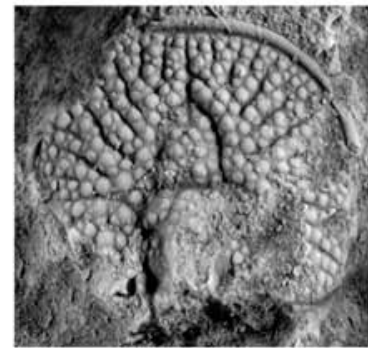

K

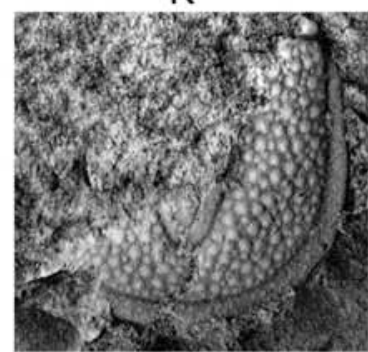

L

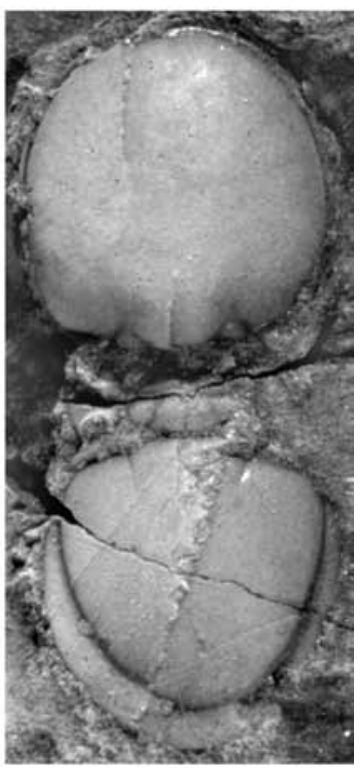

G

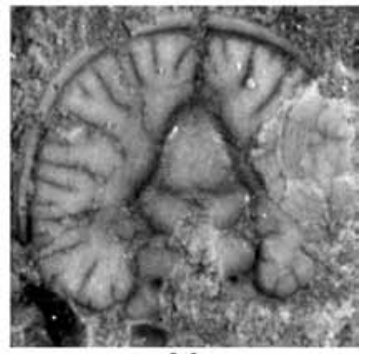

M

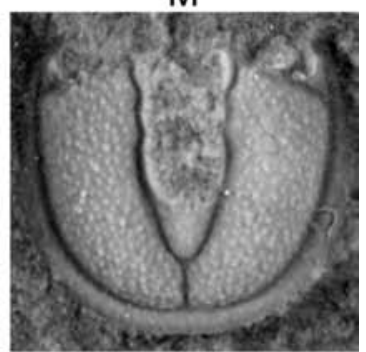

$\mathrm{N}$

Figure 9. Key agnostoid trilobite species used for recognition of the base of the Guzhangian Stage. Numbers with the prefix LYX (for Luoyixi section) indicate collecting horizons in meters above the arbitrary 0 m position. All dorsal views. A-D, Lejopyge armata (Linnarsson, 1869), a series of primitive and derived forms. A, cephalon, LYX12.50, $111.9 \mathrm{~m}$ above the base of the Huaqiao Formation, $x$ 6; B, pygidium, LYX21.45, $120.85 m$ above the base of the Huaqiao Formation, $x$ 10; $C$, cephalon, LYX27.65, $127.05 m$ above the base of the Huaqiao Formation, $x$ 8; D, pygidium, LYX27.65, $127.05 m$ above the base of the Huaqiao Formation, $x$ 8; E-G, Lejopyge calva Robison, 1964. E, cephalon, LYX 15.4, $114.8 m$ above the base of the Huaqiao Formation, $x$ 8; F, pygidium, LYX15.15, $114.55 m$ above the base of the Huaqiao Formation, $x$ 10; $G$, exoskeleton, LYX19.05, $118.45 m$ above the base of the Huaqiao Formation, $x$ 10; H-J, Lejopyge laevigata (Dalman, 1828), a series of primitive and derived forms. H, exoskeleton, LYX21.9, $121.3 \mathrm{~m}$ above the base of the Huaqiao Formation, $x$ 9; I, cephalon, LYX64.40, $163.8 m$ above the base of the Huaqiao Formation, $x$ 10; J, pygidium,. LYX64.40, $163.8 m$ above the base of the Huaqiao Formation, $x$ 10.5; K, L, Ptychagnostus aculeatus (Angelin, 1851). K, incomplete cephalon, LYX54.75, 154.15 m above the base of the Huaqiao Formation, $x$ 7; L, fragmentary pygidium, LYX17.75, $117.15 \mathrm{~m}$ above the base of the Huaqiao Formation, $x$ 7; M, $N$. Goniagnostus nathorsti (Brøgger, 1878). M, LYX15.40, $114.8 \mathrm{~m}$ above the base of the Huaqiao Formation, $x$ 11; N, pygidium, LYX15.40, $114.8 m$ above the base of the Huaqiao Formation, $x 15$.

corresponding to the first appearance of L. laevigata is near the peak of a rather long negative $\delta^{13} \mathrm{C}$ excursion of up to $0.58 \%$ (Figures 6 , 7). Strata in the upper part of the Drumian Stage are characterized by slightly negative $\delta^{13} \mathrm{C}$ values (reaching a maximum of 7.6\%o). A small positive shift, which peaks at about $0.15 \%$, coincides with the base of the L. armata Zone, and this is followed by a longer negative shift, the peak of which nearly coincides with the base of Guzhangian Stage. Oscillations in the $\delta^{13} \mathrm{C}$ curve through the rest of the unnamed stage are minor, usually ranging between -1 and $+1 \%$ (Figure 6 ). The next most distinct position in the $\delta^{13} \mathrm{C}$ curve is the base of the SPICE excursion, one of the largest positive $\delta^{13} \mathrm{C}$ excursions known from the Paleozoic, which coincides with the base of the Paibian Stage 


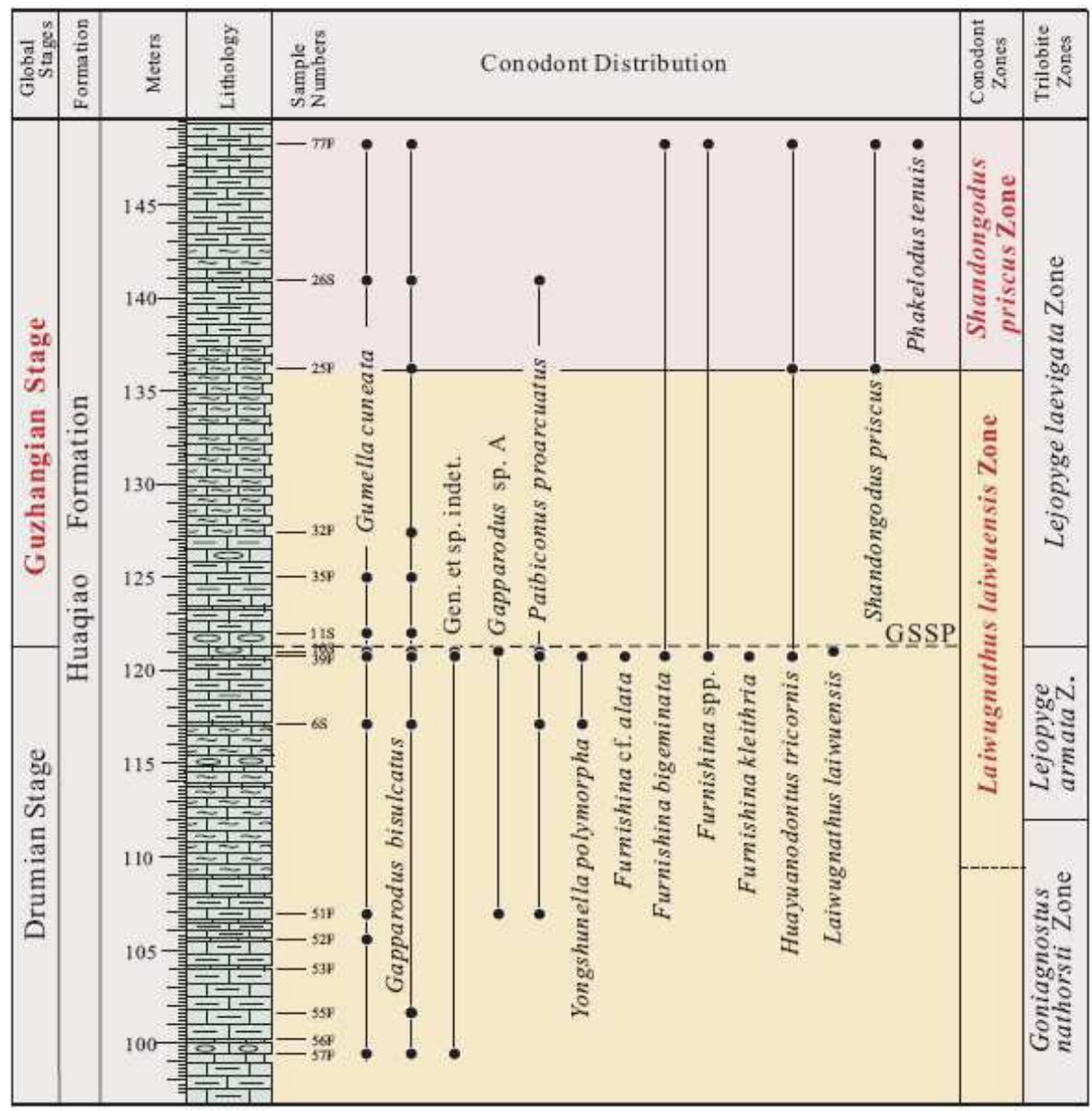

Figure 10. Observed stratigraphic distribution of conodonts in the Huaqiao Formation near the base of the Lejopyge laevigata Zone, Luoyixi section, Guzhang County, Hunan Province, China.

(Brasier and Sukhov, 1998; Montañez et al., 2000; Zhu et al., 2004).

\section{Sequence Stratigraphy}

Work in the Wuling Mountains of Hunan shows that the base of the L. laevigata Zone is associated with the early part of a transgressive event (Figures 6, 7). Overall, the Huaqiao Formation is inferred to have been deposited during eight third-order cycles (Zuo, 2006). Superimposed on these long-term cycles are a series of smaller scale transgressive-regressive cycles. Within the first third-order cycle, Zuo (2006) recognized 11 fourth-order cycles, and within the second fourth-order cycle he recognized 9 fifth-order cycles. In the Luoyixi section, the FAD of L. laevigata is associated with one of the small scale transgressive events, the lower part of the sixth fourth-order cycle (almost coinciding with the top of the first fifth-order cycle; Zuo et al., 2006, fig. 4). The species first appears less than $20 \mathrm{~cm}$ upsection of a surface inferred to represent a deepening event of small magnitude. Comparative work on sections elsewhere in Hunan Province, China (Paibi and Wangcun), and in the Great Basin, USA, shows that $L$. laevigata first appears in outer-shelf and slope lithofacies of Gondwana and Laurentia at an early stage of a transgressive event. The transgression with which the FAD of L. laevigata is associated is interpreted to be of eustatic scale.

\section{Reference Section}

Another excellent reference section exposing the Huaqiao (Jago and McNeil, 1997).
Formation in general, and the lower part of the L. laevigata Zone in particular, is located near Wangcun (across the Youshui River from the Luoyixi section), Hunan Province, China. There seems to be little difference between the Luoyixi section and the Wangcun section. The Luoyixi section was selected as the stratotype section because it has been more intensively collected in the boundary interval, making the position of the first appearance of L. laevigata more tightly constrained.

\section{Estimate of Age}

The base of the Guzhangian Stage is estimated to be $503.0 \pm 1 \mathrm{Ma}$. This figure is derived from extrapolation between the estimated age of the base of the traditional Upper Cambrian ( 500 Ma) (Shergold, 1995), which is closely correlative to the base of the Linguagnostus reconditus Zone of South China (Peng and Robison, 2000; Ahlberg, 2003; Ahlberg et al., 2004), and the estimated age of the base of the traditional Middle Cambrian (510.0 \pm 1.0 $\mathrm{Ma})$. The age of the base of the traditional Middle Cambrian is well constrained by U$\mathrm{Pb}$ ages on zircons from an ash bed in the Hanford Brook Formation, southern New Brunswick (Landing et al., 1998; Bowring and Erwin, 1998). These estimates provide a duration of about $10 \mathrm{Ma}$ for the traditional Middle Cambrian. In South China, seven to nine biozones are recognized in the

traditional Middle Cambrian (i.e., the Taijiangian and Wangcunian stages; Peng and Babcock, 2001, Yuan et al., 2002; Peng, 2003). In Australia, the same interval is covered by eight biozones (Geyer and Shergold, 2000). The average duration, then, for each zone is a little more than 1 million years. This suggests that the base of the Guzhangian Stage, coinciding with the base of the Lejopyge laevigata Zone, a level two or three biozones above the P. punctuosus Zone, is close to an age of 503.0 Ma (possibly slightly younger). This estimate accords well with a mean SHRIMP age on zircons of 503.2 $\pm 3.8 \mathrm{Ma}$ (Perkins and Walshe, 1993) for an interval probably equivalent to the Goniagnostus nathorsti Zone through the basal part of the L. laevigata Zone in the Southwell Sub-group of the Mt. Read Volcanics, Tasmania

Encarnación et al. (1999) provided dates from volcanic tuffs in the Taylor Formation, Antarctica, that provide broad support for an age close to 503.0 Ma for the base of the Guzhangian Stage. U-Pb ages on zircons recovered from slightly above and below Nilsoniaand Amphoton-bearing carbonate beds yielded a weighted mean age of $505.1 \pm 1.3 \mathrm{Ma}$. The sampled strata were interpreted as equivalent to the Floran-Undillan interval as used in Australia (Shergold et al. 1985; Shergold, 1995), but biostratigraphic control on the Taylor Formation is poor. Based on occurrences of trilobites in Australia, China, and Siberia, the sampled beds seem to be in a position near the base of the Ptychagnostus punctuosus Zone (equivalent to the Floran-Undillan boundary). 

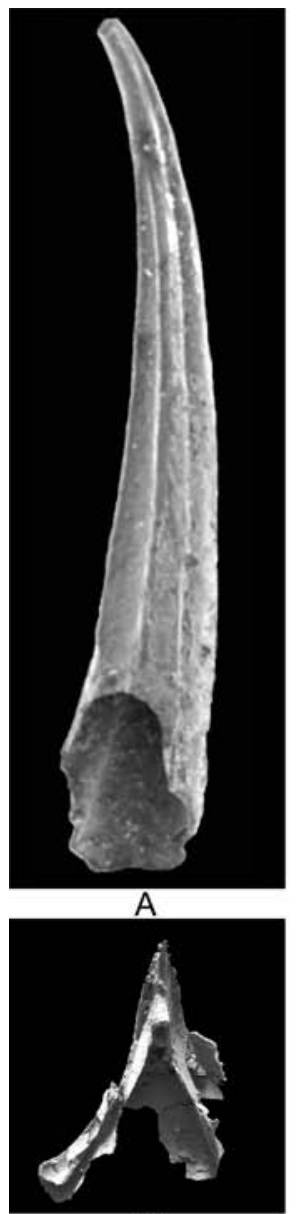

C

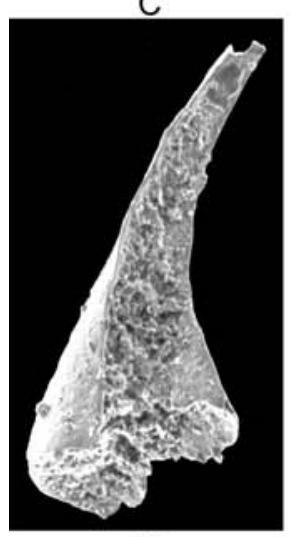

$\mathrm{E}$

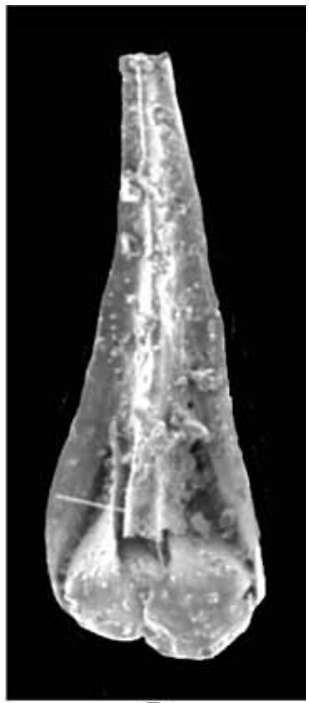

B
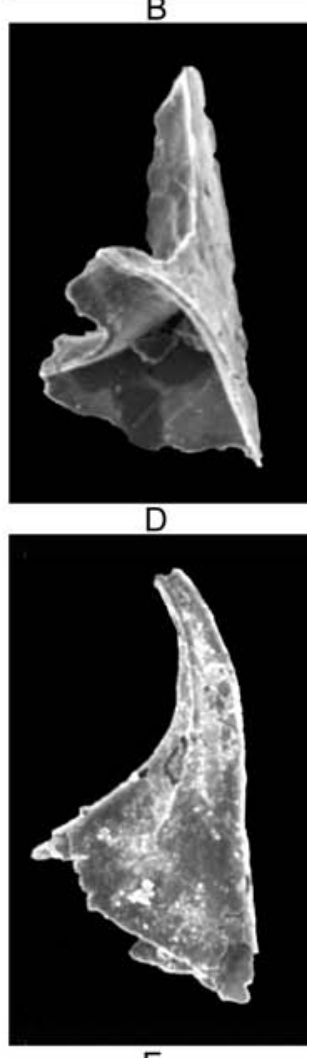

$\mathrm{F}$

Figure 11. Conodonts used for recognition of the base of the Guzhangian Stage. A, Gapparodus bisulcatus (Müller, 1959): sample 51F, $106.9 \mathrm{~m}$ above the base of the Huaqiao Formation, posterolateral view, $\times 53$; $B$, Laiwugnathus laiwuensis $A n, 1982$ : sample 10S, $121.0 \mathrm{~m}$ above the base of the Huaqiao Formation, posterior view, $\times 72 ; C$, Furnishina kleithria Müller and Hinz, 1991: sample 39F, $120.8 \mathrm{~m}$ above the base of the Huaqiao Formation, posterior view, $\times 28$; $D$, Shandongodus priscus $A n, 1982$ : sample $25 \mathrm{~F}, 136.25 \mathrm{~m}$ above the base of the Huaqiao Formation, posterolateral view, $\times 207 ; E$, Yongshunella polymorpha Dong and Bergström, 2001: sample $6 S(117.15 \mathrm{~m}$ above the base of the Huaqiao Formation), lateral view, $\times 83 ; \mathrm{F}$, Yongshunella polymorpha Dong and Bergström, 2001: sample 6S (117.15 $m$ above the base of the Huaqiao Formation), lateral view, $\times 82$.

\section{Acknowledgements}

We would like to thank all the people, including members of the ISCS, involved in the process of defining the base of the Guzhangian for stimulating discussion and scientific support. This work was supported in part by grants from the Chinese Academy of Sciences (KZCX2-YW-122), the Ministry of Science and Technology of China (2006FY120300) and National Natural Science Foundation of China (40332018) to Peng, by a grant from the U.S. National Science Foundation (EAR-0106883) to Babcock, and by a grant from National Natural Science Foundation of China (40672023) to Zuo.

References

Ahlberg, P., 2003. Trilobites and international tie points in the Upper Cambrian of Scandinavia. Geologica Acta, 1:127-134.

Ahlberg, P. Axheimer, N., Eriksson, M.E., Terfelt, F., 2004. Agnostoids and international tie points in the middle and upper Cambrian of Acandinavia. P. 108. In Mansfeld, J. (ed.), The $26^{\text {th }}$ Nordic Heological Witer Meeting, Abstract Volume (GFF, 126, part 1).

An, T.X., 1982. Study of the Cambrian conodonts from North and Northeast China. Science Report of the Institute of Geosciences, University of Tsukuba, section B 3:113-159. (in Chinese).

Axheimer, N., Eriksson, M.E., Ahlberg, P., Bengtsson, A., 2006. The middle Cambrian cosmopolitan key species Lejopyge laevigata and its biozone: new data from Sweden. Geological Magazine 143: 447-455.

Babcock, L.E., 1994. Biogeography and biofacies patterns of Middle Cambrian polymerid trilobites from North Greenland: palaeogeographic and palaeo-oceanographic implications. Grønlands Geologiske Undersøgelse Bulletin, 169: 129-147.

Babcock, L.E., Rees, M.N., Robison, R.A., Langenburg, E.S., Peng, S.C., 2004. Potential Global Stratotype-section and Point (GSSP) for a Cambrian stage boundary defined by the first appearance of the trilobite Ptychagnostus atavus, Drum Mountains, Utah, USA. Geobios, 37: 149158.

Babcock, L.E., Peng, S.C., Geyer, G., Shergold, J.H., 2005. Changing perspective on Cambrian chronostratigraphy and progress toward subdivision of the Cambrian System. Geosciences Journal, 9: 101-106

Babcock, L.E., Robison, R.A., Rees, M.N., Peng, S.C., Saltzman, M.R., 2007. The Global Stratotype Section and Point (GSSP) of the Drumian Stage (Cambrian) in the Drum Mountains, Utah, USA. Episodes, 30(2): 8494.

Bowring, S.A., Erwin, D.H., 1998. A new look at evolutionary rates in deep time: uniting paleontology and high-precision geochronology. GSA Today, 8: $1-8$.

Brasier, M.D., Cowie, J. and Taylor, M., 1994. Decision on the PrecambrianCambrian boundary. Episodes, 17: 95-100.

Brasier, M.D., Sukhov, S.S., 1998. The falling amplitude of carbon isotopic oscillations through the Lower to Middle Cambrian: northern Siberian data. Canadian Journal of Earth Sciences, 35: 353-373.

Cook, H.E., Taylor, M.E., 1975. Early Paleozoic continental margin sedimentation, trilobite biofacies, and the thermocline, western United States. Geology, 3: 559-562.

Cook, H.E., Taylor, M.E. 1976. Comparison of continental slope and shelf environments in the upper Cambrian and lowest Ordovician of Nevada. In: Cook, H.E., Enos, P. (eds.), Deep-water Carbonate Environments. Society of Economic Paleontologists and Mineralogists Special Publication, 25: 51-81.

Cooper, R.A., Jago, J.B., Begg, J.G., 1996. Cambrian trilobites from northern Victoria Land, Antarctica, and their stratigraphic implications. New Zealand Journal of Geology and Geophysics, 39: 363-387.

Cooper, R.A., Nowlan, G., Williams, S.H., 2001. Global stratotype section and point for base of the Ordovician System. Episodes, 24: 19-28. 
Cowie, J.W., Rushton, A.W.A., Stubblefield, C.J., 1972, A correlation of Cambrian rocks in the British Isles: Geological Society of London Special Report, No. 2, 42 pp.

Daily, B., Jago, J.B., 1979. The trilobite Lejopyge Hawle and Corda and the middle-upper Cambrian boundary. Palaeontology, 18: 527-550.

Davidek, K.L., Landing, E., Bowring, S.A., Westrop, S.R., Rushton, A.W.A., Fortey, R.A. and Adrain, J., 1998. New uppermost Cambrian U-Pb date from Avalonian Wales and age of the Cambrian-Ordovician boundary. Geological Magazine 133: 303-309.

Demokidov, V.A., 1968. Correlation of Arctic Cambrian strata. Trudy Nauchno-Issledovatel'skogo Instituta Geologii. Arktuka, 155, 213 pp.

Dong X.P., 1991. Late Midle and early Late Cambrian agnostids in Huayuan, Hunan. Acta Palaeontologica Sinica, 30: 439-457 (in Chinese with English abstract)

Dong X.P.,Bergström S.M., 2001. Middle and Upper Cambrian proconodonts and paraconodonts from Hunan, South China. Palaeontology 44: 949985.

Egorova, L.I., Shabanov, Y.Y., Pegel, T.V., Savitsky, V.E., Suchov, S.S., Chernysheva, N.E., 1982. Maya Stage of type locality (Middle Cambrian of Siberian platform). Academy of Sciences of the USSR, Ministry of Geology of the USSR, Interdepartmental Stratigraphic Committee of the USSR, Transactions 8: 1-146 (in Russian).

Encarnación J., Rowell, A.J., Grunow, A.M., 1999. A U-Pb age for the Cambrian Taylor Formation, Antarctica: implications for the Cambrian timescale. Journal of Geology, 1999, 107: 497-504.

Ergaliev, G.K.,1980. Trilobity srednego i verkhnego kambriya Malogo Karatau [Middle and Upper Cambrian trilobites of the Malyi Karatau Range]. Academy of Sciences, Kazakhstan SSR, Publishing House of Kazakhstan SSR, Alma-Ata, 211 pp. (in Russian).

Ergaliev, G.K., Ergaliev, F.G., 2000. Biostratigrafiya kembriya Khrebta Karatau - Ocnova obschei shkali kambriiskikh otlozhenii tsentralynoi Azii [Biostratigraphy of Cambrian of Karatau Range - basis of unified scale of Cambrian deposits of Central Asia] Izhvestiya AH Respubliki Kazakhstan, seriya geologicheckaya, 2000, 119-134.

Ergaliev, G.K., Ergaliev, F.G.., 2001. Middle Cambrian trilobites and stages of the Malyi Karatau Ridge (southern Kazakhstan). In: Peng, S.C., Babcock, L.E., Zhu, M.Y. (eds.), Cambrian System of South China. University of Science and Technology Press of China, Hefei, p. 256.

Fu, Q.L., Zhou, Z.C., Peng, S.C., Li, Y., 1999. Sedimentology of candidate sections for the Middle-Upper Cambrian boundary stratotype in western Hunan, China. Scientia Geologica Sinica, 34 (2): 204-212.

Gehling, J.G., Jensen, S., Droser, M.L., Myrow, P.M., Narbonne, G.M., 2001. Burrowing below the basal Cambrian GSSP, Fortune Head, Newfoundland. Geological Magazine, 138: 213-218.

Geyer, G., Shergold, J., 2000. The quest for internationally recognized divisions of Cambrian time. Episodes, 23: 188-195.

Grotzinger, J.P., Bowring, S.A., Saylor, B.Z., Kaufman, A.J., 1995. Biostratigraphic and geochronologic constraints on early animal evolution. Science, 270: 598-604.

Guizhou Bureau of Geology and Mineral Resources, 1987. Regional Geology of Guizhou Province. People's Republic of China, Ministry of Geology and Mineral Resources, Geological Memoirs, series 1, number 7. Geological Publishing House, Beijing, 698 pp.

Hunan Bureau of Geology and Mineral Resources, 1988. Regional Geology of Hunan Province. People's Republic of China, Ministry of Geology and Mineral Resources, Geological Memoirs, series 1, number 8. Geological Publishing House, Bejing, 719 pp.

Hutchinson, R.D., 1962. Cambrian stratigraphy and trilobite faunas of southeastern Newfoundland. Geological Society of Canada Bulletin, 88: $1-156$.

Jago, J.B., 1975. Late Middle Cambrian agnostid trilobites from the Gunns Plains area, northwestern Tasmania. Papers and Proceedings of the Royal Society of Tasmania, 110: 1-18.

Jago, J.B., Brown, A.V., 2001. Late Middle Cambrian trilobites from Trial Range, southwestern Tasmania. Papers and Proceedings of the Royal Society of Tasmania, 135: 1-14.
Jago, J.B., McNeil, A.W., 1997. A late Middle Cambrian shallow-water trilobite fauna from the Mt. Read Volcanics, northwestern Tasmania. Papers and Proceedings of the Royal Society of Tasmania, 131:85-90.

Khairullina, T.I., 1970. Trilobity Maiskogo yarusa Turkestanskogo khrebta [Trilobite of the Maya Stagein the Turkestan Region]. In: Shayukuboe, T.S. (ed.), Biostratigrafia osadochnykh obrazovanii Uzbekistan, vol. 9: 5-30. Tashkentskij Geologorazvedochnyj Trest "Tashkentgeologiya", kompleksnaya Geologo'semochnaya Ekspeditsiya, Leningrad branch of "Hedra" Publishing House, Leningrad (in Russian).

Khairullina, T.I. 1973. Biostratigrafiia trilobity maiskogo yarus srednego Kembriia Turkestanskogo Khrebta [Trilobite biostratigraphy of the Middle Cambrian Maya Stage in the Turkestan ranges]. Central Asiatic Institute of Geology and Mineral Resources, Tashkent., $112 \mathrm{pp}$.

Landing, E., 1994. Precambrian-Cambrian boundary global stratotype ratified and a new perspective of Cambrian time. Geology, 22: 179-182.

Landing, E., Bowring, S.A., Davidek, K.L., Rushton, A.W.A., Fortey, R.A., Wimbledon, W.A.P., 2000. Cambrian-Ordovician boundary age and duration of the lowermost Ordovician Tremadoc Series based on U-Pb zircon dates from Avalonian Wales. Geological Magazine, 137: 485-494.

Landing, E., Bowring, S.A., Davidek, K.L., Westrop, S.R., Geyer, G., Heldmaier, W., 1998. Duration of the Cambrian: U-Pb ages of the volcanic ashes from Avalon and Gondwana. Canadian. Journal of Earth Sciences, 35: 329-338.

Landing, E., Peng, S.C., Babcock, L.E., Geyer, G., Moczydlowska-Vidal, M. 2007. Global standard names for the lowermost Cambrian series and stage. Episodes, 30:287-289.

Laurie, J.R., 1988. Revision of some Australian Ptychagnostinae (Agnostida, Cambrian). Alcheringa, 12: 169-205.

Laurie, J.R., 1989. Revision of Goniagnostus Howell and Lejopyge Corda from Australia (Agnostida, Cambrian). Alcheringa, 13: 175-191.

Lu, Y.H., Lin, H.L., 1989. The Cambrian trilobites of western Zhejiang. Palaeontologia Sinica, 57:317-328

Montañez, I.P., Osleger, D.A., Banner, J.L., Mack, L.E., Musgrove, M., 2000. Evolution of the $\mathrm{Sr}$ and $\mathrm{C}$ isotope composition of Cambrian oceans. GSA Today, 10(5): 1-7.

Öpik, A.A., 1961. Early Upper Cambrian fossils from Queensland. Australia Bureau of Mineral Resources, Geology and Geophysics Bulletin, 53: 1249.

Öpik, A.A., 1967. The Mindyallan fauna of northwestern Queensland. Australia Bureau of Mineral Resources, Geology and Geophysics Bulletin 74, volume 1, text, $404 \mathrm{pp}$.; volume 2, plates, $167 \mathrm{pp}$.

Öpik, A.A., 1979. Middle Cambrian agnostids: systematics and biostratigraphy. Australia Bureau of Mineral Resources, Geology and Geophysics Bulletin 172, volume 1, text, 188 pp.; Volume 2, plates 1-67.

Palmer, A.R., 1968. Cambrian trilobites from east-central Alaska. United States Geological Survey, Professional Paper 559B, 115 pp.

Peng, S. C., 2003. Chronostratigraphic subdivision of the Cambrian of China. Geologica Acta, 1:135-144.

Peng, S.C., 2005. Potential candidate stratotypes for the levels of Lejopyge laevigata and Agnostotes orientalis. Acta Micropaleontologica Sinica, 22 (Supplement): 148-149.

Peng, S.C., 2006. A new global framework with four series for Cambrian System. Journal of Stratigraphy, 30 (2): 147-148.

Peng, S.C., Babcock, L.E., 2001. Cambrian of the Hunan-Guizhou Region, South China. In: Peng, S.C., Babcock, L.E., Zhu, M.Y. (eds.), Cambrian System of South China. Palaeoworld, 13. Press of University of Science and Technology of China, Hefei, pp. 3-51.

Peng, S.C., Babcock, L.E., Geyer, G., Moczyd³owska, M., 2006. Nomenclature of Cambrian epochs and series based on GSSPs - Comments on an alternative proposal by Rowland and Hicks. Episodes, 29: 130-132.

Peng, S.C., Babcock, L.E., Lin, H.L., Chen, Y.G., Zhu, X.J., 2001. Cambrian stratigraphy at Wangcun, Hunan Province, China: stratotypes for bases of the Wangcunian and Youshuian stages. In: Peng, S.C., Babcock, L.E., Zhu, M.Y. (eds.), Cambrian System of South China. Palaeoworld, 13. Press of University of Science and Technology of China, Hefei, pp.151161. 
Peng, S.C., Babcock, L.E., Robison, R.A., Lin, H.L., Rees, M.N. Saltzman, M.R. 2004a. Global Standard Stratotype-section and Point (GSSP) of the Furongian Series and Paibian Stage (Cambrian). Lethaia, 37: 365379.

Peng, S.C., Babcock, L.E., Lin H.L. 2004b. Polymerid trilobites from the Cambrian of northwestern Hunan, China. Volume 1: Corynexochida, Lichida, and Asaphida. Science Press, Beijing, 333 pp.

Peng, S.C., Babcock, L.E., Zuo, J.X, Lin, H.L., Zhu, X.J., Yang, X.F., Robison, R.A., Qi, Y.P., Bagnoli, G., 2006. Proposed GSSP for the base of Cambrian Stage 7, coinciding with the first appearance of Lejopyge laevigata, Hunan, China. Palaeoworld, 15: 367-383.

Peng, S.C., Babcock, L.E., Zuo, J.X., Lin, H.L., Cheng, Y.A., Zhu, X.J., Yang, X.F., Li, Y., 2005. Cambrian-Ordovician stratigraphy at Luoyixi and Wangcun, Hunan Province, China: stratotypes for bases of the Wangcunian and Youshuian stages, and candidate stratotypes for bases of global stages of the Cambrian. In: Peng, S.C., Babcock, L.E., Zhu, M.Y. (eds), Cambrian System of China and Korea. University of Science and Technology of China Press, Hefei, p. 117-135.

Peng, S.C., Robison, R.A. 2000. Agnostoid biostratigraphy across the middle-upper Cambrian boundary in Hunan, China. Paleontological Society Memoir 53, supplement to Journal of Paleontology, 74(4): 1-104.

Peng, S.C., Zhu, X.J., Babcock, L.E., Wang H.F., 2004c. Potential global stratotype sections and points in China for defining Cambrian stages and series. Geobios 37: 253-258.

Perkins, C., Walshe, J.E., 1993. Geochronology of the Mount Read Volcanics, Tasmania, Australia. Economic Geology, 88:1176-1197.

Pokrovskaya, N.V., 1958. Agnostidy srednego Kembriya yakutii [Agnostoids from the Middle Cambrian of Yakutia, part 1], chastci 1. Akademiya Nauka SSSR, Trudyeologicheskogo Instituta, 16: 1-96.

$\mathrm{Pu}$, X.C., Ye, H.Z., 1991. Cambrian sedimentary facies and palaeogeography framewok in southern China. Collected Papers of Lithofacies and Paleogeography 6: 1-16 (in Chinese with English abstract).

Rees, M.N., Robison, R.A., Babcock, L.E., Chang, W.T., Peng, S.C., 1992. Middle Cambrian eustasy: evidence from slope deposits in Hunan Province, China. Geological Society of America Abstracts with Programs, 24 (7): A108

Remane, J., Basset, M.G., Cowie, J.W., Gohrbandt, K.H., Lane, H.R., Michelsen, O., Wang, N.W., 1996. Revised guidelines for the establishment of global chronostratigraphic standards by the International Commission on Stratigraphy (ICS). Episodes, 19: 77-81.

Robison, R.A., 1964a. Late Middle Cambrian faunas from western Utah. Journal of Paleontology, 38: 510-566.

Robison, R.A., 1964b. Upper Middle Cambrian stratigraphy of western Utah. Geological Society of America Bulletin, 75: 995-1010

Robison, R.A., 1976. Middle Cambrian trilobite biostratigraphy of the Great Basin. Brigham Young University Studies in Geology, 23: 93-109.

Robison, R.A., 1984. Cambrian Agnostida of North America and Greenland, Part I, Ptychagnostidae. University of Kansas Paleontological Contributions, Paper 109: 1-59.

Robison, R..A., 1988. Trilobites of Holm Dal Formation (late Middle Cambrian), central North Greenland. Meddelelser om Grønland, Geoscience, 20: 23-103.

Robison, R.A., 1994. Agnostoid trilobites from the Henson Gletscher and Kap Stanton formations (Middle Cambrian), North Greenland. Grønlands Geologiske Undersøgelse Bulletin, 169: 25-77.
Robison, R.A., 1999. Lithology and fauna of the Lejopyge calva Zone. In: Palmer, A.R. (ed.), Laurentia 99. V Field Conference of the Cambrian Stage Subdivision Working Group, International Subcommission on Cambrian Stratigraphy. Institute for Cambrian Studies, Boulder, p. 21.

Robison, R.A., 2001. Subdividing the upper part of the Cambrian System: a suggestion. In: Peng, S.C., Babcock, L.E., Zhu, M.Y (eds.), Cambrian System of South China. University of Science and Technology of China Press, Hefei, p. 298.

Robison, R.A., Rosova, A.V., Rowell, A.J. Fletcher, T.P., 1977. Cambrian boundaries and divisions. Lethaia, 10: 257-262.

Rowell, A.J., Robison, R.A., Strickland, D.K., 1982. Aspects of Cambrian phylogeny and chronocorrelation. Journal of Paleontology, 56: 161-182.

Shergold, J.H., 1995. Timescale 1. Cambrian. Australian Geological Survey Organization, Record 1995/30.

Shergold, J.H., Geyer, G. 2001. The International Subcommission on Cambrian Stratigraphy: progress report 2001. Acta Palaeontologica Sinica, 40 (Supplement): 1-3.

Shergold, J.H., Geyer, G., 2003. The Subcommission on Cambrian Stratigraphy:the status quo. In Aceñolaza, G.F. (ed.), Advances in the Knowledge of the Cambrian System. Geologica Act,a 1:5-9.

Shergold, J.H., Jago, J., Cooper, R., Laurie, J., 1985. The Cambrian System in Australia, Antarctica, and New Zealand. Correlation charts and explanatory notes. IUGS Publication 19: 1-85.

Tortello, M.F., Bordonaro, O.L., 1997. Cambrian agnostoid trilobites from Mendoza, Argentina: a systematic revision and biostratigraphic implications. Journal of Paleontology, 71: 74-86.

Westergård A.H., 1946. Agnostidea of the Middle Cambrian of Sweden. Sveriges Geologiska Undersökning (series C), 477, $141 \mathrm{pp}$.

Yang, J.L., 1978. Middle and Upper Cambrian trilobites of western Hunan and eastern Guizhou. Professional Papers of Stratigraphy and Palaeontology, 4:1-82 (in Chinese).

Yang, J.L., Yu S.Y., Liu, G.T., Su, N.M., He, M.H., Shang, J.G., Zhang, H.Q., Zhu, H.Y., Li, Y.J., Guo, G..S., 1991. Cambrian stratigraphy, lithofacies, paleogeography and trilobite faunas of East Qinling-Dabashan Mountains, China. Press of China University of Geosciences Press, Wuhan, $246 \mathrm{pp}$.

Yuan, J.L., Zhao, Y.L., Li, Y., Huang, Y.Z., 2002. Trilobite fauna of Kaili Formation (uppermost Lower Cambrian-lower Middle Cambrian) from southeastern Guizhou, South China. Shanghai Publishing House of Science and Technology. Shanghai, $423 \mathrm{p}$.

Zhu, M.Y., Zhang, J.M., Li, G.X., Yang, A.H., 2004. Evolution of C isotopes in the Cambrian of China: implications for Cambrian subdivision and trilobite mass extinctions. Geobios, 37: 287-301.

Zuo J.X., 2006. Characteristics of Carbon and Isotopic Composition of Cambrian Carbonates, South China: Postdoctoral Report of the Nanjing Institute of Geology and Palaeontology, Chinese Academy of Sciences, Nanjing, China, 171 pp.

Zuo, J.X, Peng, S.C., Zhou C.M., Yan C.H., Liu G.Y., 2006. Tectonic significance and sedimentary characteristics of turbidity successions within the Cambrian Huaqiao Formation at Wancun section in the west Hunan, South China. Acta Sedimentologica Sinica, 24: 175-184.

Zuo, J.X, Peng, S.C., Zhu, X.J., Qi, Y.P., Lin, H.L., Yang, X.F., 2008. Evolution of carbon isotope composition in potential Global Stratotype Section and Point at Luoyixi, South China, for the base of the global seventh stage of Cambrian System. Journal of China University of Geosciences: 19(1): 9-22. 
Shanchi Peng is a Research Professor at the Nanjing Institute of Geology and Palaeontology, Chinese Academy of Sciences (CAS) and a Professor at the Graduate School, CAS. He has been working on Cambrian stratigraphy and Cambrian and Ordovician trilobite paleontology since 1978. Currently he focuses his research in developing formal global and Chinese chronostratigraphy of Cambrian System. He is Vice-Chairman of the International Commission on Stratigraphy (ICS) and Chairman of the International Subcommission on Cambrian Stratigraphy (ISCS).

Loren E. Babcock is a Professor in the School of Earth Sciences at The Ohio State University, Columbus, Ohio, USA. His research interests are centered around trilobite paleobiology, taphonomy, and stratigraphy. In recent years, much of Babcock's work has focused on development of a global chronostratigraphic subdivision of the Cambrian System. He is Secretary of the International Subcommission on

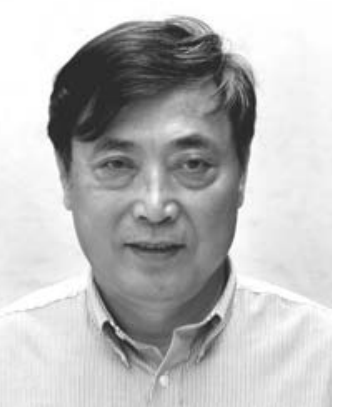

Jingxun Zuo is a researcher at the Henan Institute of Geological Survey, Zhengzhou, Henan Province, China, where he is currently serving as Deputy Chief Engineer. His research interests are in sedimentology and chemostratigraphy, with a focus on Cambrian and Triassic isotopic stratigraphy, especially on the studies of carbon and oxygen isotope evolutions for the intervals of potential GSSPs in the upper half of Cambrian and the lower Triassic in South China.
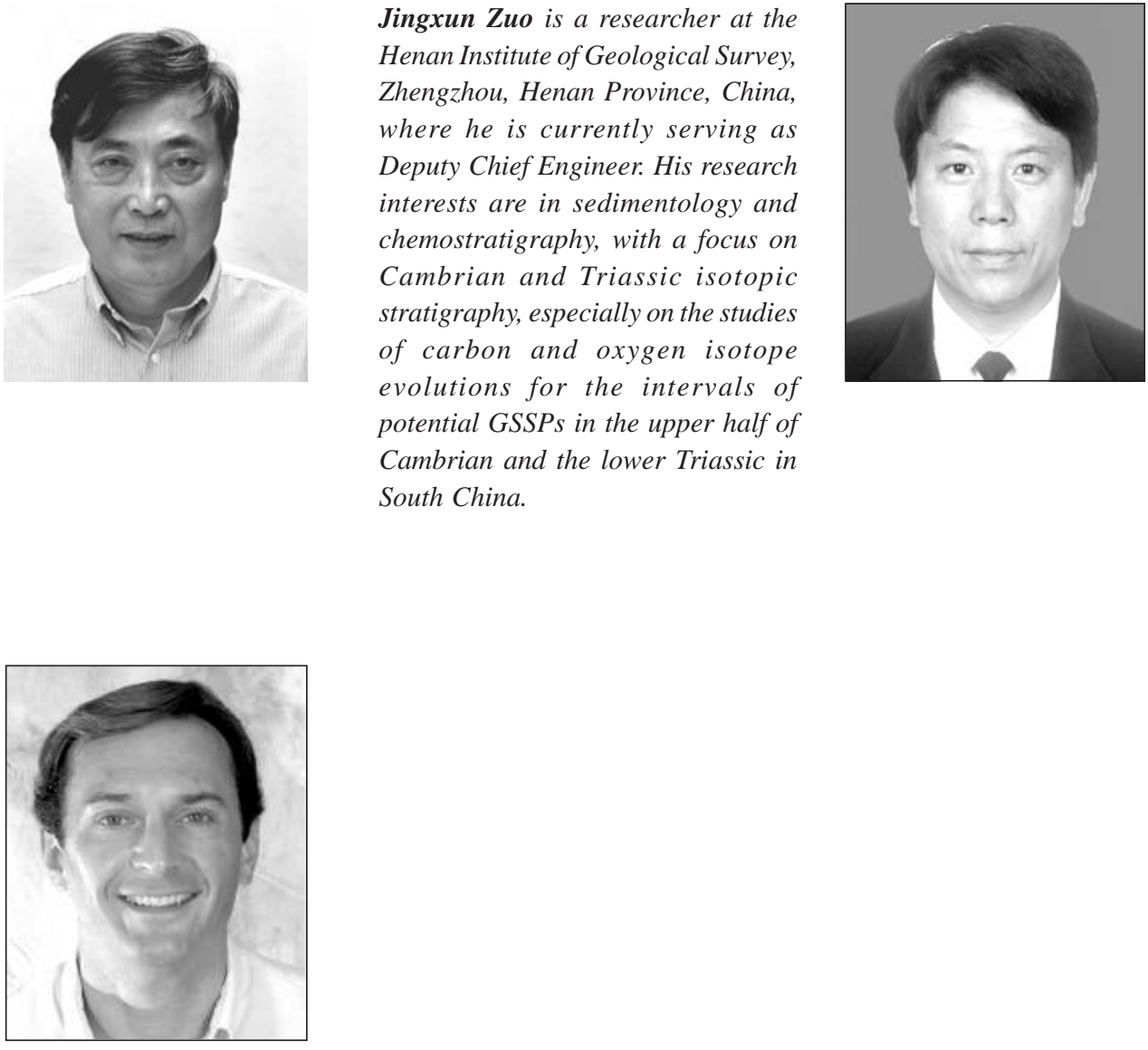

Cambrian Stratigraphy. 